\title{
CHANNEL, DUNE AND SAND SHEET ARCHITECTURES OF STRAIT-ADJACENT DELTAS, RIFIAN CORRIDOR, MOROCCO
}

\author{
DAAN BEELEN*1 ${ }^{1}$, LESLI WOOD ${ }^{1}$, MOHAMED NAJIB ZAGHLOUL $^{2}$, SEBASTIAN \\ CARDONA $^{1}$ and MICHIEL ARTS ${ }^{3}$ \\ ${ }^{1}$ SAnD Consortium, Colorado School of Mines, Golden, CO, USA, dbeelen@mines.edu, 1500 \\ Illinois street, Golden, CO, USA. shows
}

Email:lwood@mines.edu,geocardona9@gmail.com

${ }^{2}$ Université Abdelmalek Essaâdi, Tangier, Morocco, zaghloul@geologist.com

${ }^{3}$ Université de Liège, Belgium, michiel.arts@stratigraphy.eu

*Correspondence (daanbeelengeologist@gmail.com)

Twitter: @daanosaurus_rex

This manuscript is a preprint published on June 17th, 2021 in the preprint server EarthArXiv. It has also been submitted for publication in Geological Society of London Special Publication: Straits and Seaways: controls, processes and implications in modern and ancient systems. Although the contents of this preprint are true and complete according to the authors; future versions may have slightly different wording or figures. Please contact the lead author Daan Beelen (dbeelen@mines.edu) if you have any questions or comments about this preprinted manuscript.

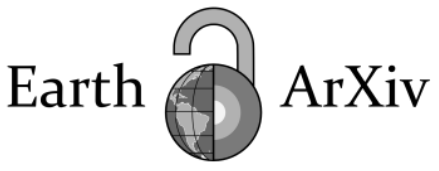




\begin{abstract}
Sea strait geographies amplify tidal currents, which can result in the formation of tidal strait deposits with a symmetrical facies arrangement. It can be problematic to distinguish such confined tidal strait deposits from strait systems that developed in less constricted settings. To push a more robust differentiation between the confined tidal strait model and a model for less constricted tidal deposits, this study presents an example of a strait-adjacent delta and compares it to the existing model of confined tidal straits. The strait-adjacent delta interpretations are based on an exposed succession in Northern Morocco, that formed in the Miocene Rifian Corridor. The multi-km, seismic-scale exposures at the Ben Allou locality, formed in a region with a largely unconstrained coastline. Clayey and silty portions dominate the distal offshore and prodelta facies, while the proximal delta front and delta plain are comprised of carbonate-rich sandstones. These sandstones exhibit complex architectures of stacked channels and dunes in the delta front, and mud drapebearing sand sheets on the delta plain. It is shown that the strait-adjacent delta model that is presented herein, is different from a confined tidal strait deposit as it has an asymmetric facies arrangement, and a basinward reduction in depositional energy.
\end{abstract}




\section{INTRODUCTION}

Straits, seaways, corridors and gateways, (henceforth all called: straits) are elongate basin geometries that connect two separate depocenters. Such geographies play a key role in oceanographic processes as they regulate the direction and magnitude of ocean currents. Straits are also prone to confine and thereby amplify tidal currents (e.g. Longhitano, 2013). River deltas that deliver sediment to these straits therefore tend to have some significant degree, if not dominance of tidal processes that sculpt their morphology (Longhitano, 2013; Niehuis et al., 2020). Tidal straits are typically rapidly filled with sediment or eliminated by tectonics and are thus relatively short-lived but common in the geological record (Rossi et al., 2017). Due to their importance as relatively widespread sedimentary deposits and usefulness as a record for palaeoclimatic and tectonic events, strait deposits have received a relatively large amount of research attention (Longhitano et al., 2012). Despite this, owing to the intricate confluence of wave, tide and fluvial processes in tidal strait areas, and the typically complex structural and basinal settings of strait-fill sediments, many sedimentary and stratigraphic characteristics of strait depositional systems remain not fully understood. For example, the confined tidal strait model by Longhitano, (2013) has proven to be an effective tool for predicting facies distributions where the overall palaeogeography and geological setting is narrow and well constrained, but significant problems persist in areas with wider and a more complex palaeogeography. For example, the Miocene Betic Corridor is less like a relatively simple tidal strait configuration like the Messina Strait or San Francisco Bay area, and more like an archipelago containing islands and multiple, partially connected straits and seaways, similar to present-day Greece or Indonesia. For deposits that formed in these complex areas, it may be difficult to constrain coastline trends in high enough accuracy to confidently apply a confined tidal strait model like the one from Longhitano, (2013), but many factors generally associated with tidal straits are present here, like tidal amplification, basinward facies coarsening and shore parallel tidal currents.

This study focusses on deposits that formed in a complex geography, namely the Moroccan Rifian Corridor. During the late Miocene, this area was a series of sea straits that joined the Atlantic Ocean to the Mediterranean Sea (Fig. 1). Palaeogeographic reconstructions show that the Rifian

Corridor was comprised of at least two main sea straits known as the Southern and Northern Rifian Corridors (Abassi et al., 2020; Krijgsman et al., 1999), and contained an unknown number of Rif 'islands', which together formed an archipelago (Krijgsman et al., 1999; Achalhi et al., 2016; Capella et al., 2017; Fig. 1). This relatively wide (40-80 km) and relatively shallow (200-400 m) marine zone can therefore best be referred to as the 'Rifian Archipelago' but is typically called the Rifian Corridor or, Rifian Seaway. Regardless of its broader palaeogeographic interpretation, it is well understood that this area had complex, rugose coastline arrangement and an extensive shallow marine shelf system and was situated at the southern margin of the Rif Foreland Basin (Bernini et al., 2000; Capella et al., 2017). However, despite extensive fieldwork and reflection seismic analysis by Zizi et al. (1996) and outcrop work by Capella et al. (2017), the precise palaeogeographic extent and coastline orientation of the Rifian Archipelago remains largely undefined. It is expected that the overall palaeogeography of the Rifian Archipelago was roughly 
analogous to the contemporaneous Betic Corridor or 'Betic Archipelago' which was located in what is now Southern Spain. This area's palaeogeography is arguably slightly better constrained than for Rifian Corridor and can best be described as having an erratically distributed coastline with islands, tidal straits, bays, and inlets (Martín et al., 2014).

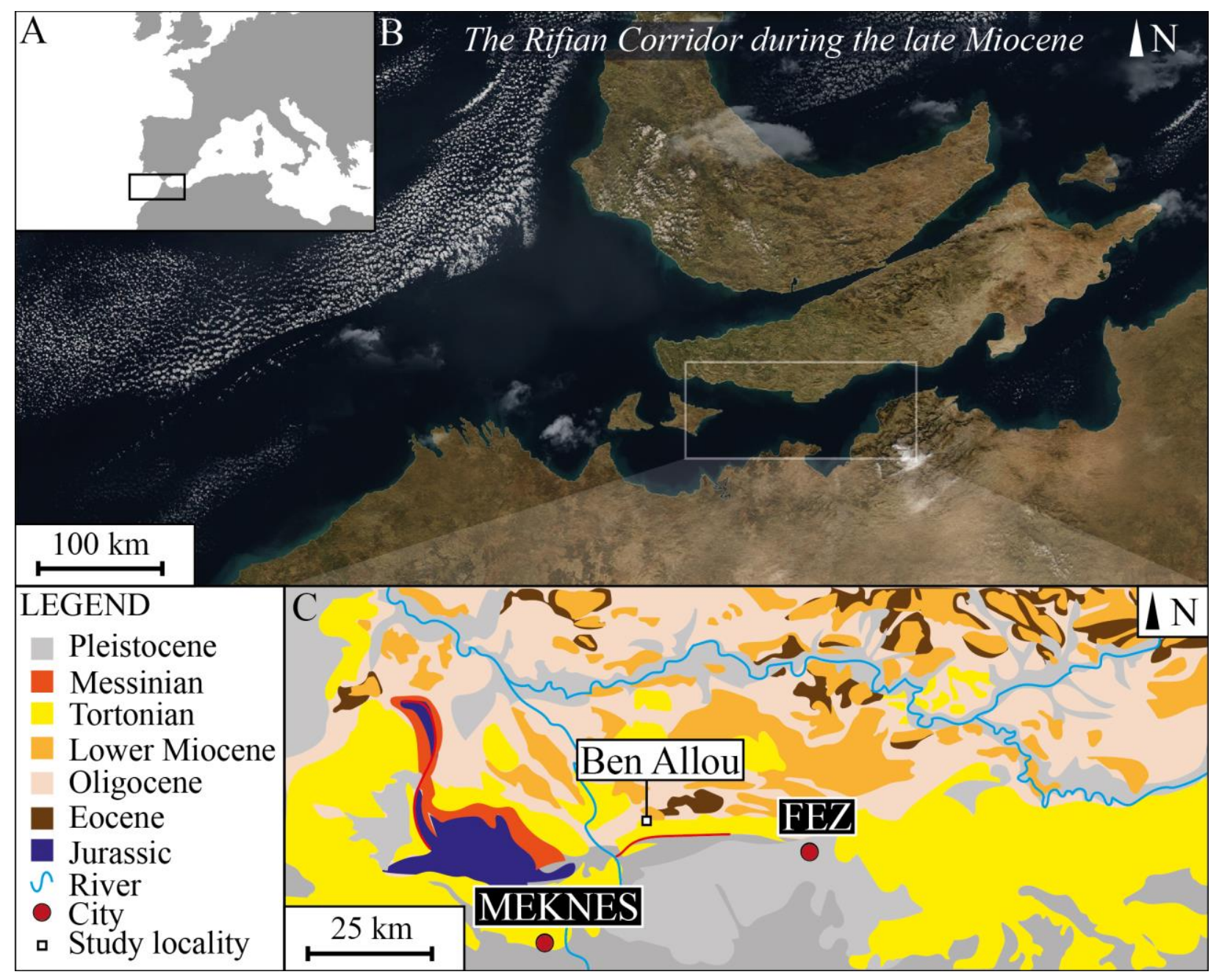

Figure 1. A: Present-day location of the study area relative to the European continent. B: Schematic palaeogeographic reconstruction of the Rifian Corridor or, Rifian Archipelago during the late Tortonian (late Miocene). Note that the Strait of Gibraltar had not yet formed during this time (modified from Capella et al. (2017a)). White box represents area of image shown below. C: Geological map showing the location of the Ben Allou locality relative to the cities of Meknes and Fez. Geological map is modified from Chenakeb (2004). All outcrop localities considered in this study are from the upper Tortonian interval of the Saïs sub-basin in the Rif Foreland. 


\section{Basinal Setting}

The sea straits and marine regions of the Rifian Corridor were contained within the Rif Foreland Basin. This basin originated from compressional stresses associated with the northward movement of the African Continent. The bulk of the sedimentary infill of the Rif Foreland took place during the Miocene, when nappes pilled onto the hinterland of the Rifian foreland basin, leading to an increase in the subsidence due to crustal bending (Achalhi et al., 2016; Iribarren et al., 2009). The additional accommodation that originated from this subsidence, was rapidly filled by a northward prograding sedimentary wedge, accumulating to about $1.400 \mathrm{~m}$ thickness (Iribarren et al., 2009; Roldan 2014). The sediments that were deposited on the southern margin of the Rif Foreland are mostly fine grained marine marls and siltstones (e.g. the extensive 'Blue Marl Formation' Bernini et al., 2000). To a lesser extent, there are carbonaceous sandstones and some siliciclastic deep sea fan deposits that are mostly further to the north (Iribarren et al., 2009). This study focusses on an exposed portion of upper Tortonian Rifian Corridor fill, that formed in a sub basin of the Rif Foreland called the Saïss-sub Basin (Abassi et al., 2020). These sedimentary rocks contain the regionally extensive, fine grained 'blue marl' facies (Bernini et al., 2000), and also some well exposed carbonaceous sandstone units. The locality of this exposure is roughly $30 \mathrm{~km}$ northwest of the city of Fez, and is called Ben Allou, or sometimes Sidi Chahed (e.g. de Weger et al., 2020). The outcrops at Ben Allou are some of the most studied and laterally complete Rifian Corridor outcrops (Capella et al., 2017). This exposed succession has been biostratigraphically age constrained to the late Tortonian: 7.2 to 7.5 Ma (Capella et al., 2017). Shortly after the Tortonian, in the Messinian stage, continuation of the compressive tectonics between the African and European plates caused a tightening and eventual closure of the Rifian Corridor, as well as the contemporaneous Betic Corridors. This separated the Mediterranean Sea from the Atlantic Ocean and causing the prevailing evapotranspiration in the Mediterranean Sea to precipitate thick deposits of evaporites, which marks a globally significant event known as the as the 'Messinian salinity crisis' (Roveri et al., 2014). Following this event, continued northward motion of the African continent caused the Saïss-sub basin to become faulted and rotated, and up-thrusted onto the Rifian orogenic wedge (Roldán et al., 2014). Despite this, much of the Saïss-sub basin sediments, including those that are now exposed at Ben Allou, avoided deep burial, and were subject to a relatively limited amount of structural deformation and folding in the Ben Allou outcropping area.

\section{Aims and objectives}

The aims of this study are to present an outcrop-specific approach, where the sedimentary features and stratigraphic architectures are analysed independently of existing palaeogeographic estimates. This study therefore is a test-case, where limited availability of regional data, precludes a priori assumptions regarding the environmental setting of the depositional systems but forces the analysis to consider a wide range of possible depositional settings like narrow and wide sea straits. This study can therefore improve depositional environment interpretations of strait-fill sediments, or depositional systems that formed in a complex and poorly defined, elongate basinal setting or 
archipelago. Because of the large, $\mathrm{km}$-scale exposures and the extensive sandstone intervals at Ben Alou, a particular emphasis is given on describing and interpreting the stratigraphic architectures and associated sedimentological processes across various facies environments. Specifically, the aims are to use the outcrops at Ben Allou to describe: 1) How does the sea strait depositional palaeogeography affect the development of bedform architectures and trace fossils 2), how does the strait-adjacent model differ from the confined tidal strait model and the non-strait-adjacent model?

\section{METHODS}

Stratigraphic logs were measured in the field. Facies characterizations were based on in field observations and observations of sedimentary structures that are visualized on photos and photomosaics. To accurately capture surfaces and sedimentary architectures, high-resolution photomosaics of the sandstone units were made by assembling 10-35 optically zoomed photos. Gamma radiation was measured every $50 \mathrm{~cm}$ across key portions of the sedimentary sections using a RS-230 BGO Super-SPEC Handheld Gamma Ray Spectrometer. These spectral gamma ray (SGR) data were used to map grainsize trends and mineralogy and origin of the clay sediments (e.g. Adams and Weaver, 1958; Schlumberger, 2013).

\section{RESULTS}

The outcrops at Ben Allou ( $\left.34^{\circ} 5^{\prime} 52.78^{\prime} \mathrm{N}, 5^{\circ} 18^{\prime} 32.43^{\prime} \mathrm{W}\right)$, are a succession of alternating fine grained claystone/siltstone units (facies 1 and 2 respectively), and coarse grained sandstone units (facies 3, 4 and 5). These alternating units occur in a cyclic arrangement, with the fine grained facies 1 and 2 at the bottom, which progresses upward through the coarse grained facies 3, 4 and finally facies 5, which defines the top of each cycle (Fig. 2). The cyclic development of five facies occurs three times in the rocks at Ben Allou. The relatively erosion resistant nature of the sandstones, facies (3, 4 and 5) led to the formation of well-exposed continuous cliffs at Ben Allou, which extend over a roughly $1 \mathrm{~km}$ wide and $2.5 \mathrm{~km}$ long area near Lake Sidi Chahed (Fig. 3). The Ben Allou outcrops follow the contours of a hillside and expose a wide range of sedimentary structure orientations. Most of the sediment exposed at Ben Allou are the fine grained facies, accounting for $74 \%$ of the succession, which interbed the sandstone units. These fine grained facies have limited fossils and sedimentary structures preserved. In contrast, the sandstones have abundant sedimentary structures and other environmental and process indicators like trace fossils. This makes the coarse grained facies more useful for inferring depositional architectures and process history of the Ben Allou deposits. Most bedform and palaeoenvironment descriptions are therefore focused on the sandstone facies (3, 4 and 5). 
A Ben Allou Ben Allou, upper cycle Ben Allou, upper sandstone unit

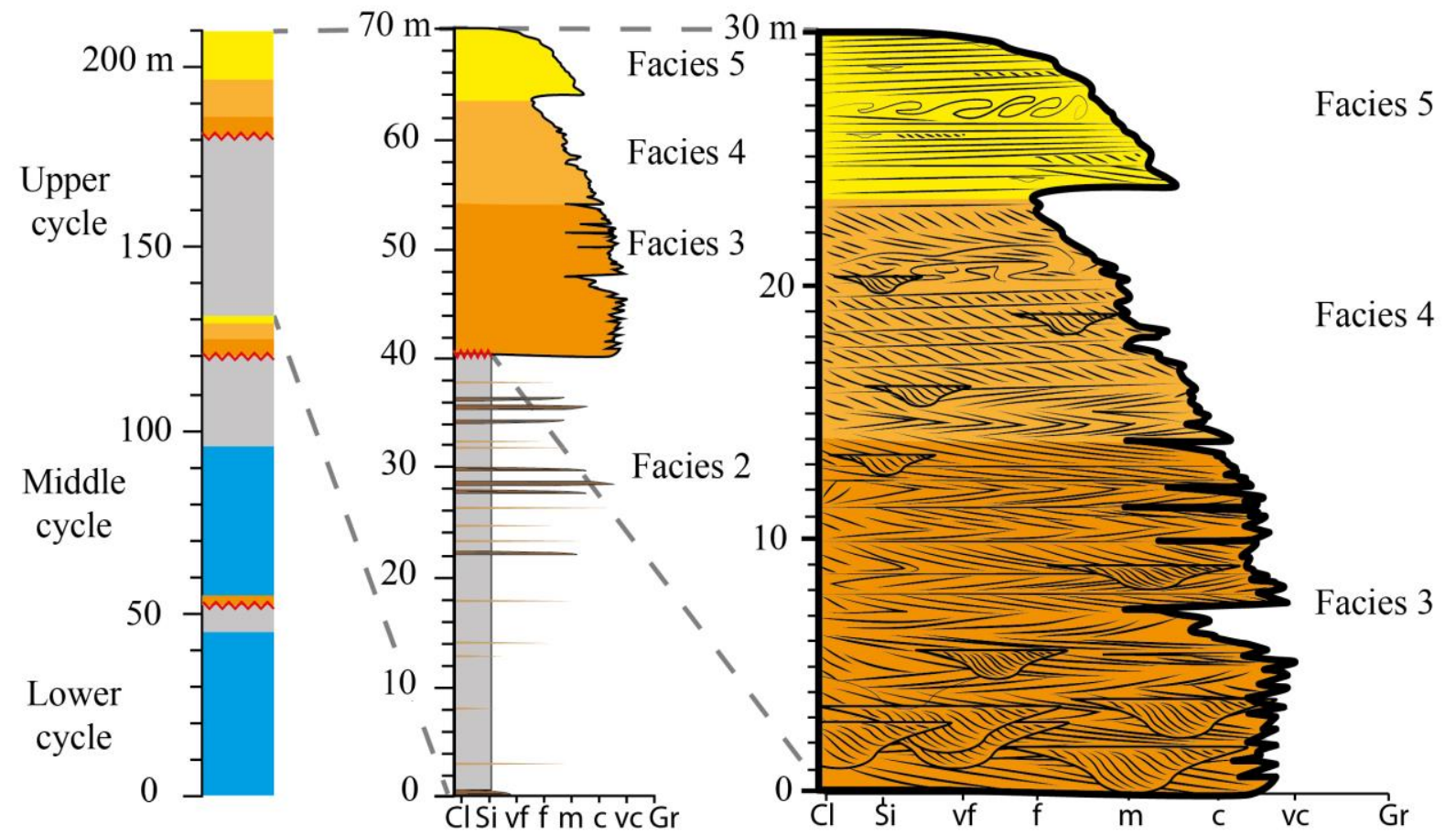

\section{B LEGEND \\ Facies 5 \\ Facies 4 \\ Facies 3 \\ Facies 2 \\ Facies 1}

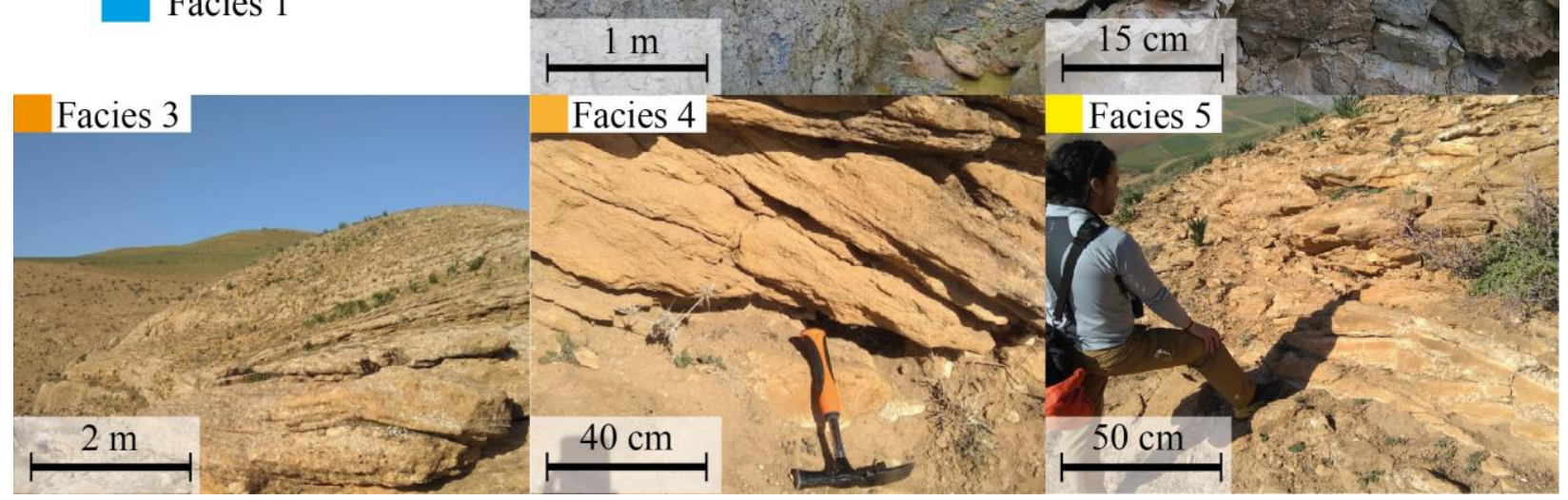

Figure 2. A: Stratigraphic log of the Ben Allou exposure, total stratigraphic thickness is $209 \mathrm{~m}$. There are three cycles of roughly $70 \mathrm{~m}$ thickness. Second log shows the upper cycle which contains facies 2-5. Third log shows detail of upper sandstone unit containing facies 3-5, B: Photos showing all five facies. 

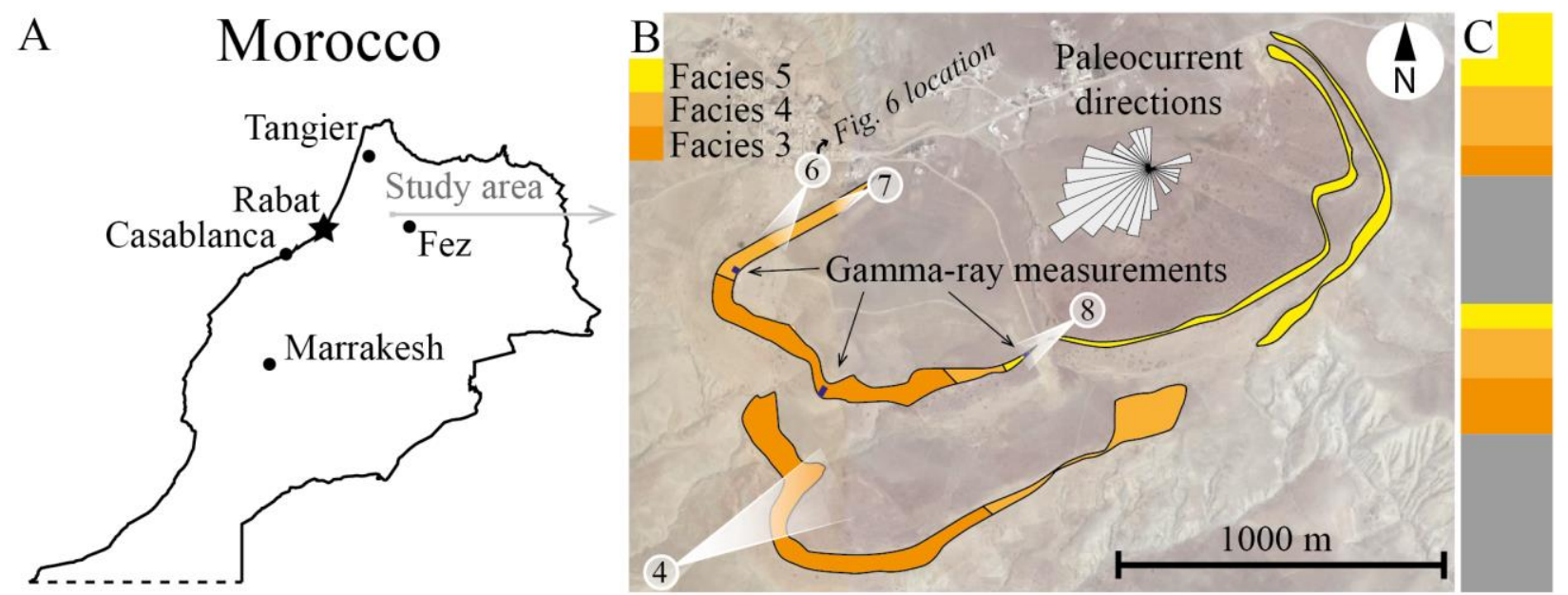

Figure 3. A: Map of Ben Allou outcrops within the country of Morocco. B: Satellite Map view of the outcrops at Ben Allou, note large extent of the outcrop $( \pm 1 \mathrm{~km}$ wide and $\pm 2.5 \mathrm{~km} \mathrm{long})$. Coloured polygons identify cliff-forming sandstone units belonging to facies 3,4 and 5, Grey rose diagram shows the overall palaeocurrent direction which is dominantly southwest. Dark blue lines show location of continuous gamma ray measurements. White view boxes indicate the various interpretations panels of facies 3, 4 and 5. Numbers accompanying view boxes correspond to figure numbers. $C$ : Schematic log of the sedimentary succession, colours correspond to legend in $B$ and legend in Fig. 2.

\section{Facies 1: Claystones}

Facies 1 are fine grained silt-bearing claystones, that contain $21 \% \mathrm{CaCO}_{3}$. This facies is homogenous and does not contain any sedimentary structures (Fig. 2B). Some preserved organic matter is present in these rocks. Trace fossils are small, (1-2 $\mathrm{mm}$ thick), relatively common Chondrites.

\section{Facies 2: Siltstones}

Facies 2 are grey siltstones that contain a higher portion $\mathrm{CaCO}_{3}$ than facies $1(41 \%)$. These siltstones coarsen upwards slightly. Although these facies are generally homogeneous (Fig. 2) and lacking in sedimentary structures, they are occasionally interbedded with much coarser $5-15 \mathrm{~cm}$ thick sandstone layers. These sandstone layers are comprised of heavily damaged and broken microfossils and shell fragments and are capped by finer ripple laminated siltstones. $5-10 \mathrm{~cm}$ sand stringers and some intervals of planar laminations are also present in facies 2 (Fig. 2B). Trace fossils are rare and are mostly bivalve casts.

\section{Facies 3: Thick cross stratified sandstones}

The upper boundary of the siltstones are sharp, laterally extensive erosional boundaries that separate facies 2 from facies 3 . Facies 3 are medium to coarse grained, thick cross stratified 
sandstones. Lower boundary basal surfaces of facies 3 are the most important surfaces at Ben Allou, displaying a sudden rapid coarsening of sediments across a boundary that extends for multiple kilometres across the entire outcrop (Fig. 4). Sandstones belonging to facies 3 can also be called packstones (sensu Dunham, 1962) or calcarenites due to their high mass percentage of $\mathrm{CaCO} 3(60 \%)$. They are yellow-brown carbonate-rich shell fragments, with some siliciclastic material that is comprised mostly of immature, sometimes euhedral quartz grains with rare euhedral garnets. The dominant sedimentary structures that are abundant throughout facies 3 are cross strata, reactivation surfaces and rhythmic bedding of heterolithic coarse and fine sandstones. Cross strata in facies 3 are relatively large with high-angle foresets, and cross-stratified intervals are separated by straight or inclined surfaces. Trough cross stratification is sometimes apparent in facies 3 and is most clearly visible when facing opposite to the dominant palaeocurrent direction (Fig. 3). Cross stratal thicknesses range from $0.5 \mathrm{~m}$ to $4 \mathrm{~m}$ thick, and through cross strata are between 16 and $40 \mathrm{~m}$ wide. Roughly one meter thick bidirectional current structures (Abouessa et al., 2014) are also present here. Facies 3 contain numerous large 15-120 m wide and 3-12 m thick channels (Fig. 5). These features are typically isolated, but some channels are amalgamated near the boundary between facies 2 and 3 . Channels have a distinct two-tiered, 'bullhorn'-shaped crosssectional geometry and are filled with rhythmically bedded, cross-stratified sandstones. The channel-fill is more resistant to erosion and weathering than the surrounding sandstones, and sometimes forms steep or vertical cliffs. Palaeocurrents are dominantly southwest with some cross strata trending in the opposite direction. 
A $\quad$ Facies 3

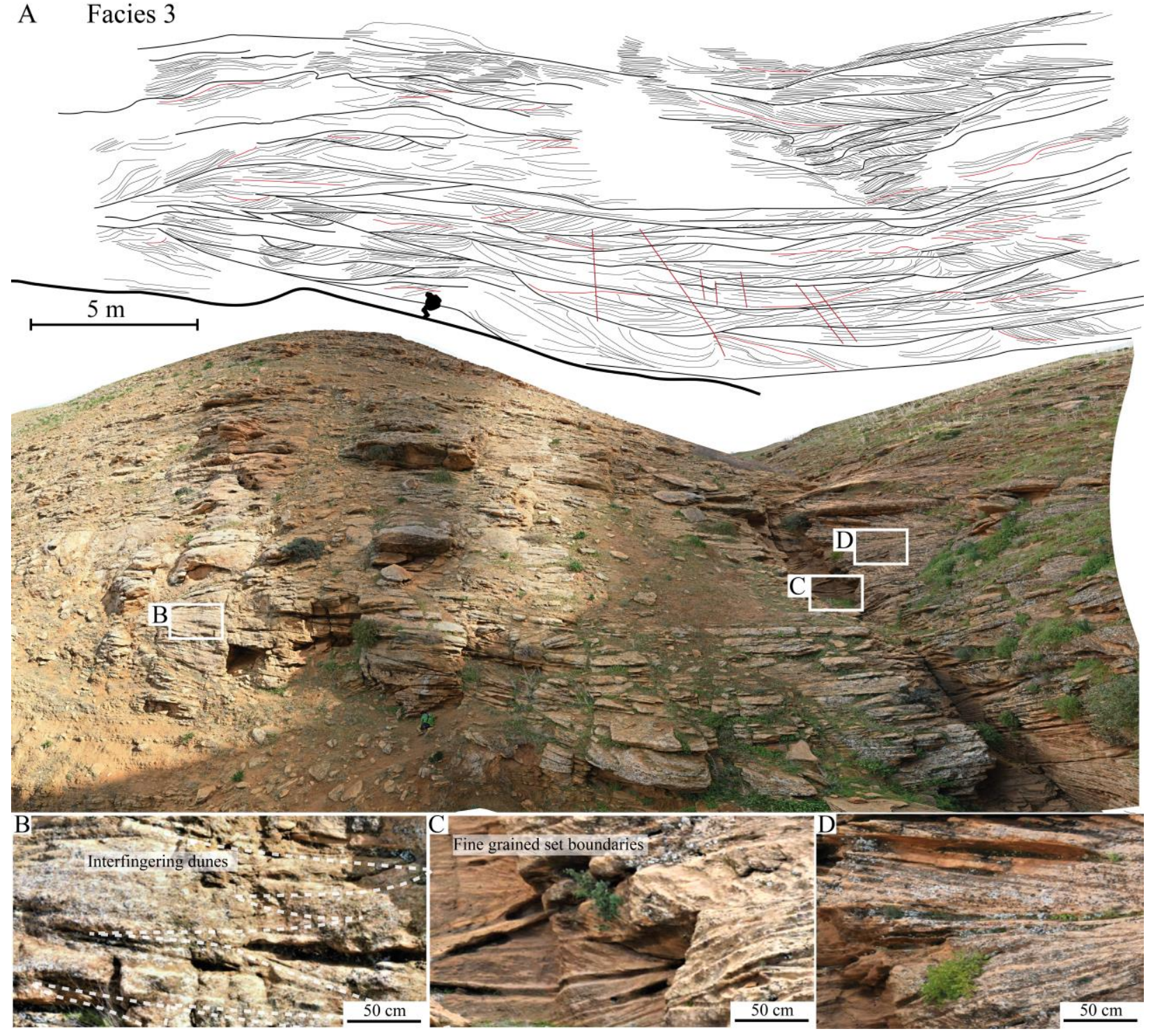

Figure 4. A: Interpretation panel of stacked 3D dunes in facies 3. Dominant palaeocurrent is towards the viewer, showing large scale through cross bedding. Note person for scale. Dune thickness to width ratio is around 1:10. Thickest black line marks lower sharp boundary between facies 2 and 3. Thick black lines are set boundaries that compartmetalise dune sets. Thin black lines are dune foresets. Red lines are reactivation surfaces. Dark red lines are small faults. B: Interfingering dunes. C: A recent gully that has erosion, exposing unweathered dune set boundaries with fine grained sediments. D. Through cross-bedding and 'false herringbones' between two dunes. 
Ichnogenera here mostly horizontal burrows and burrow networks, with Macaronichnus, Thalassinoides and Scolicia ichnogenera being most common. In some cases, bioturbation is so intense that small-scale sedimentary structures (e.g. ripples) are not preserved. Most burrows here are large, 2-4 cm thick, but overall, ichnofossils have medium diversity in size and genera and are consistent with the marine softground Cruziana ichnofacies (Gingras and MacEachern, 2012). Gamma radiation across the facies 3 sandstones ranges from 15 to 125 API, with channel deposits having a slightly higher amount gamma radiation of $>80$ API. Facies 3 has only small variability in the amount of gamma radiation, both showing $15-70$, rarely $>70$ API variations.
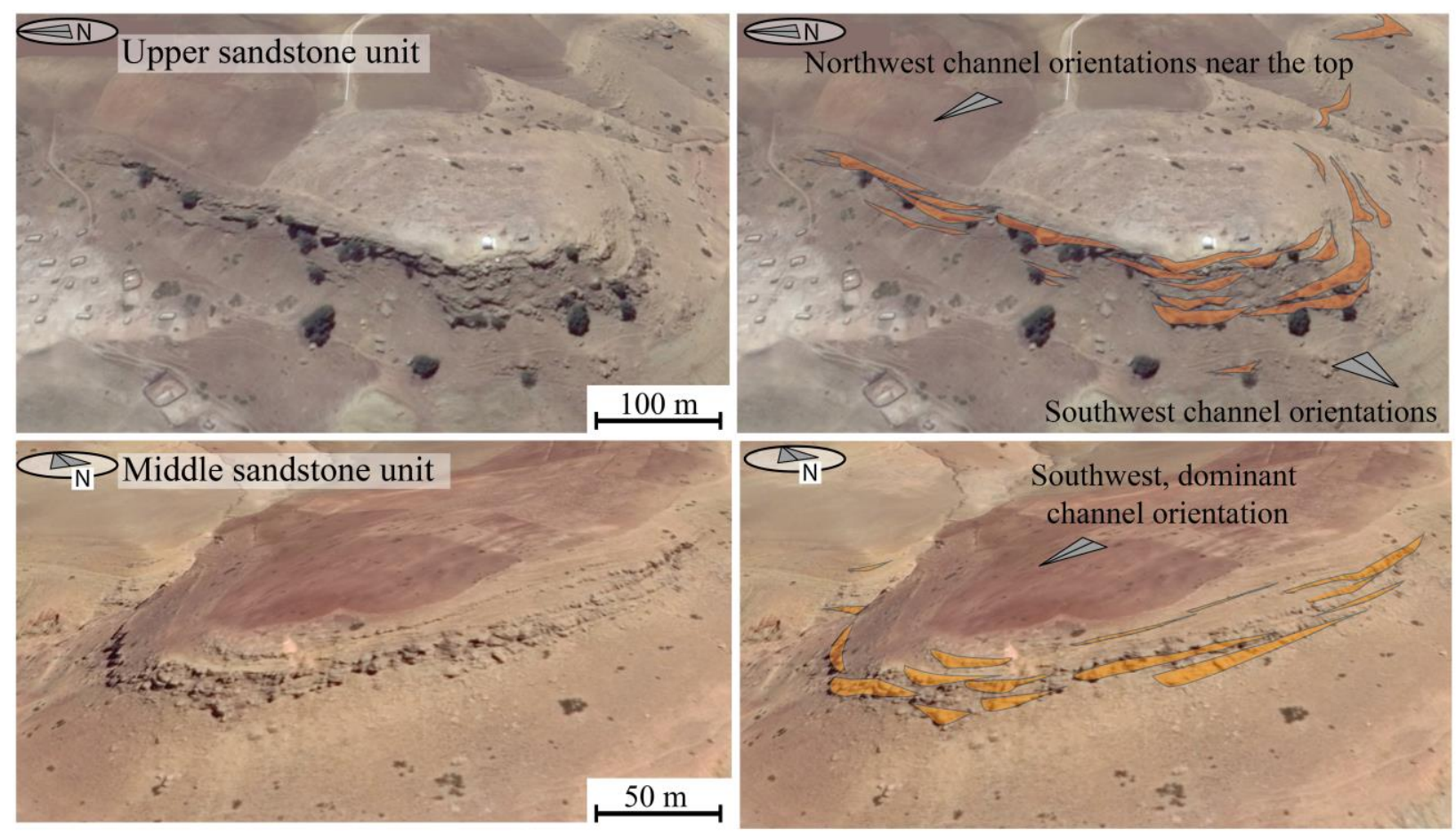

Figure 5. Satellite image showing the locations and extent of large channels in facies 3 and 4. Top shows the upper sandstone unit, bottom shows the middle sandstone unit. The largest channels are roughly $120 \mathrm{~m}$ wide and $12 \mathrm{~m}$ thick and are filled with cross stratified sandstones.

\section{Facies 4: Thin cross stratified sandstones}

Facies 4 gradually overlies facies 3 and is characterized by $50-150 \mathrm{~cm}$ thick planar cross-stratified sandstone intervals, these cross strata are thus significantly thinner than in facies 3 (Fig. 6). The sandstone facies are rhythmically bedded, containing 1-to-20 $\mathrm{cm}$ thick alternations of coarse to fine sandstones. Some sandstones contain layers of muddy rip-up clasts. The minimum grainsize here is fine sand, and intact muddy strata are not present. In some cases, $2-5 \mathrm{~cm}$ thick layers have been eroded, leaving gaps in the outcrop. Channels in these facies are relatively small at 10-12 m wide and 2-3 m thick. These channels are filled with inclined heterolithic strata that have abundant bioturbation and rapidly alternating grainsize variations. Occasionally, the channels contain well- 
cemented medium to coarse sands. Palaeocurrent directions are the same as in facies 3 , oriented dominantly southwest. Palaeocurrent directions here are slightly more consistent than in facies 3 . Facies 4 has abundant inclined heterolithic stratifications, comprised of $\pm 50 \mathrm{~cm}$ thick diagonal cross strata that are typically truncated at the top by roughly horizontal surfaces (Figs. 6; 7). Ichnofossils assemblages are dominated by Thalassinoides and Scolicia, and thus similar to facies 3, with the exception that rare Psilonichnus and Planolites ichnogenera are occasionally present in here (Pemberton and Frey, 1984).

Facies 4 emit the lowest overall gamma radiation, with an average API of 55. These portions also have the most consistent response, with limited variations in gamma ray emissions.
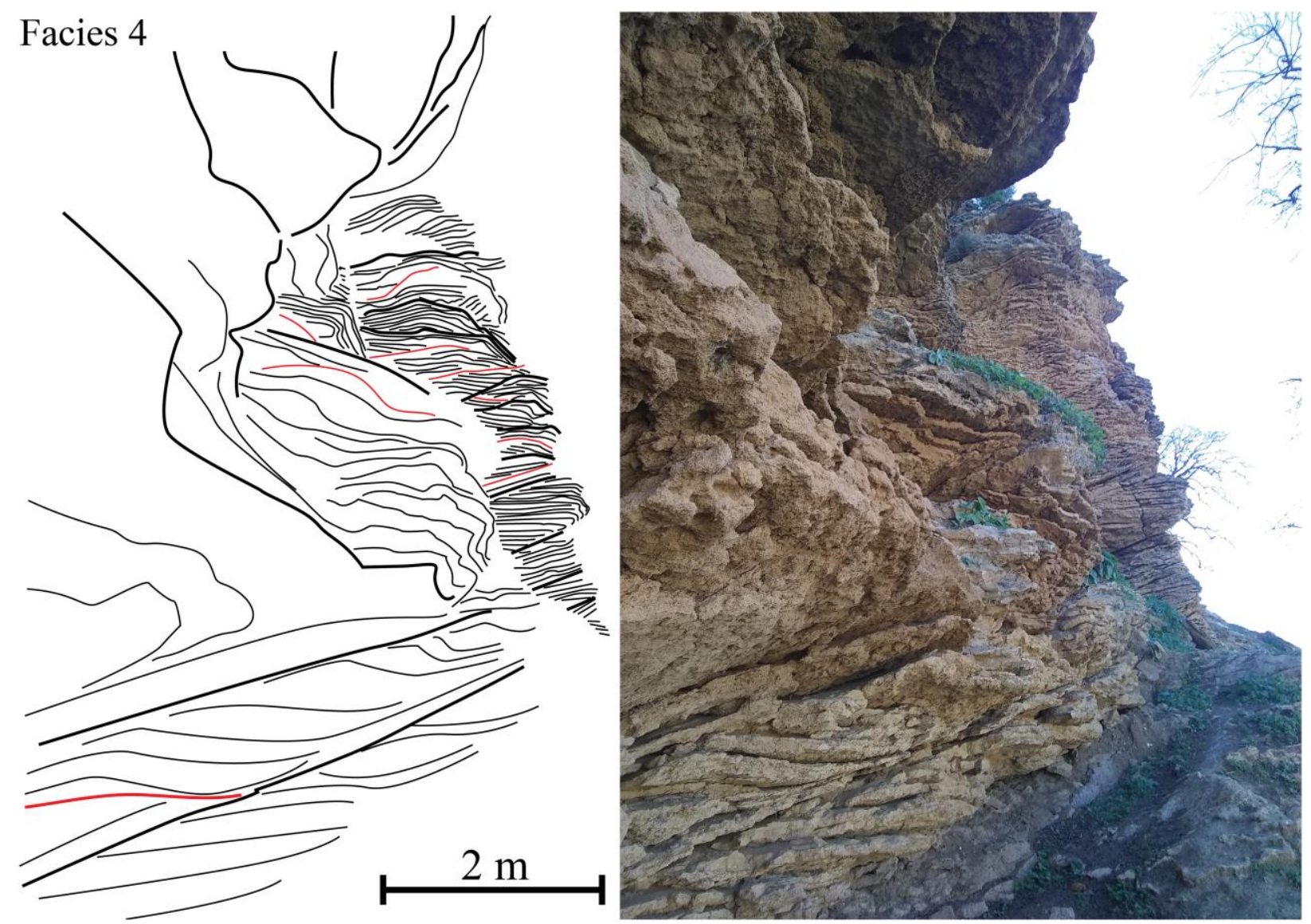

Figure 6. Interpretation panel showing an interval of stacked thin dunes characteristic of facies 4. Dunes can be represented by sigmoidal or diagonal cross strata. Thick black lines are set boundaries that compartmetalise dune sets. Thin black lines are dune foresets. Red lines are reactivation surfaces. 


\section{Facies 5: Sand sheets}

Facies 5 gradually overlies facies 4 and is characterized by a much lower abundance of cross strata, but a dominance of sheeted sandstone architectures here referred to as sand sheets (Figs. $7 ; 8$ ). Sand sheets are $10-40 \mathrm{~cm}$ thick, tabular sandstone layers with occasional low-angle cross strata (Fig. 8) and are commonly separated by $1-5 \mathrm{~cm}$ thick mud drapes, that sometimes contain small mud cracks. 1-2 m thick packages of sand sheets are sometimes contained within thicker $(5-10$ cm thick) muddy layers (Fig. 8). Thicker mud drapes are often surrounded by flaser bedding, which is characterized by multi-directional current ripples and rapidly alternating sandstones and claystones. Mud drapes can be severely weathered or missing entirely in some locations, leaving deep, roughly planar voids in the rocks. Some rare intervals have $10-30 \mathrm{~cm}$ thick cross strata with poorly visible inclined heterolithic stratifications. Unlike in facies 3 and 4, these cross-stratified intervals are not laterally extensive and only occur across several meters of lateral distance. Facies 5 has several, 2-5 $\mathrm{m}$ thick intervals with extensive slumping and syn-depositional faulting (Fig. 8). These slumped intervals are comprised of warped sand sheets. Large channels are absent in these facies but small, $100-200 \mathrm{~cm}$ wide and 10-30 cm deep channel features are occasionally present. These small channel features are filled with slightly coarser sandstones than the surrounding sand sheets. Due to the rarity of cross strata, palaeocurrent directions are difficult to obtain but appear to have dominantly northwest direction. In some cases, the surfaces of the sand sheets have ripple laminations, comprised of current ripples and symmetrical ripples (Fig. 8). Ripple laminations are mostly symmetrical ripples and thus do not exhibit a dominant direction. Larger hummocks and swales are present, most prominently near the gradual boundary with the underlying facies 4 (Fig. 7). Some of the rippled surfaces coincide with extensive bioturbation, with a high ichnodiversity, containing ichnogenera that are not present in the other sandstone facies (facies 3 and 4) like Rhizocorallium and Phytoplasma. Ichnofossils in these facies are generally small in size, Trace fossils are on average smaller than those in facies 3 and 4 and are associated with surface feeding and sub-vertical boring, with the most common ichnogenera being Psilonichnus and then, Planolites. Ichnofossils have high diversity in size and genera and are most consistent with the marine hardground Glossifungites ichnofacies (Pemberton and Frey, 1984; Gingras and MacEachern, 2012). Facies 5 has a relatively high variability in gamma radiation and alternate between mud-bearing \pm 90 API and non-mud bearing \pm 60 API sandstones (Fig. 9A). 
Facies 5 (top of section)

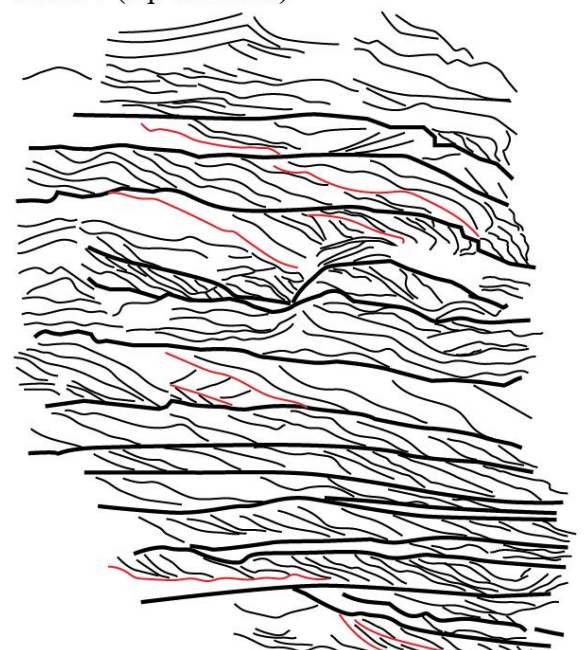

Facies 4 (bottom of section)

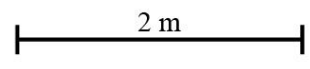

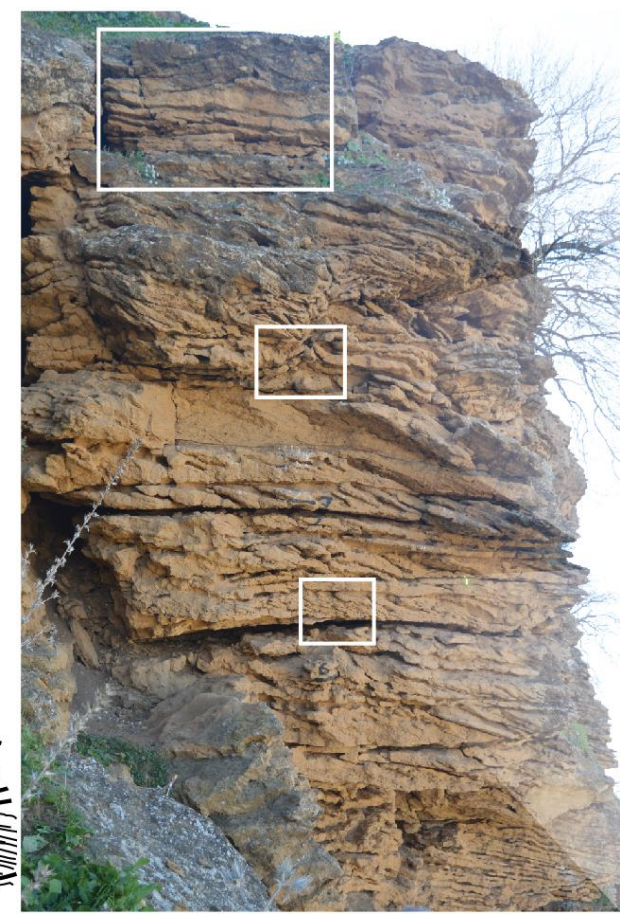

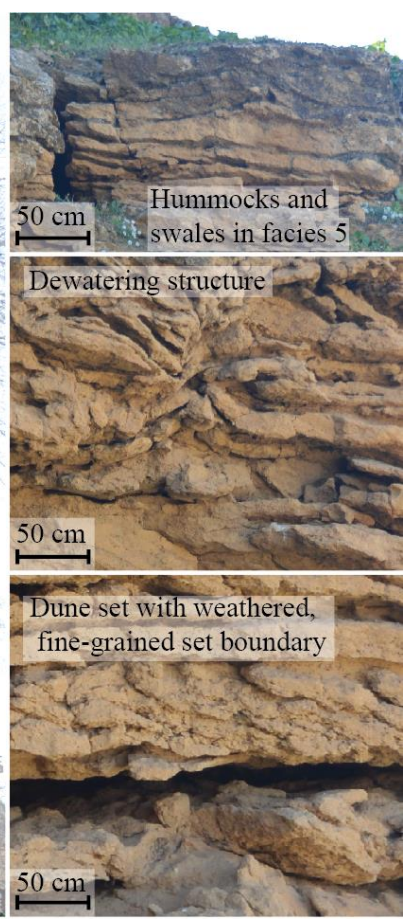

Figure 7. Interpretation panel showing an interval of stacked thin dunes characteristic of facies 4 at the bottom, and sand sheets with swales characteristic of facies 5 at the top. Note that there is a gradual boundary between facies 4 and 5. Thin black lines mark foresets, thick black lines mark set boundaries and red lines mark reactivation surfaces. Close-up photos show swales in facies 5 , a dewatering structure and a weathered set boundary in facies 4.

Facies 5

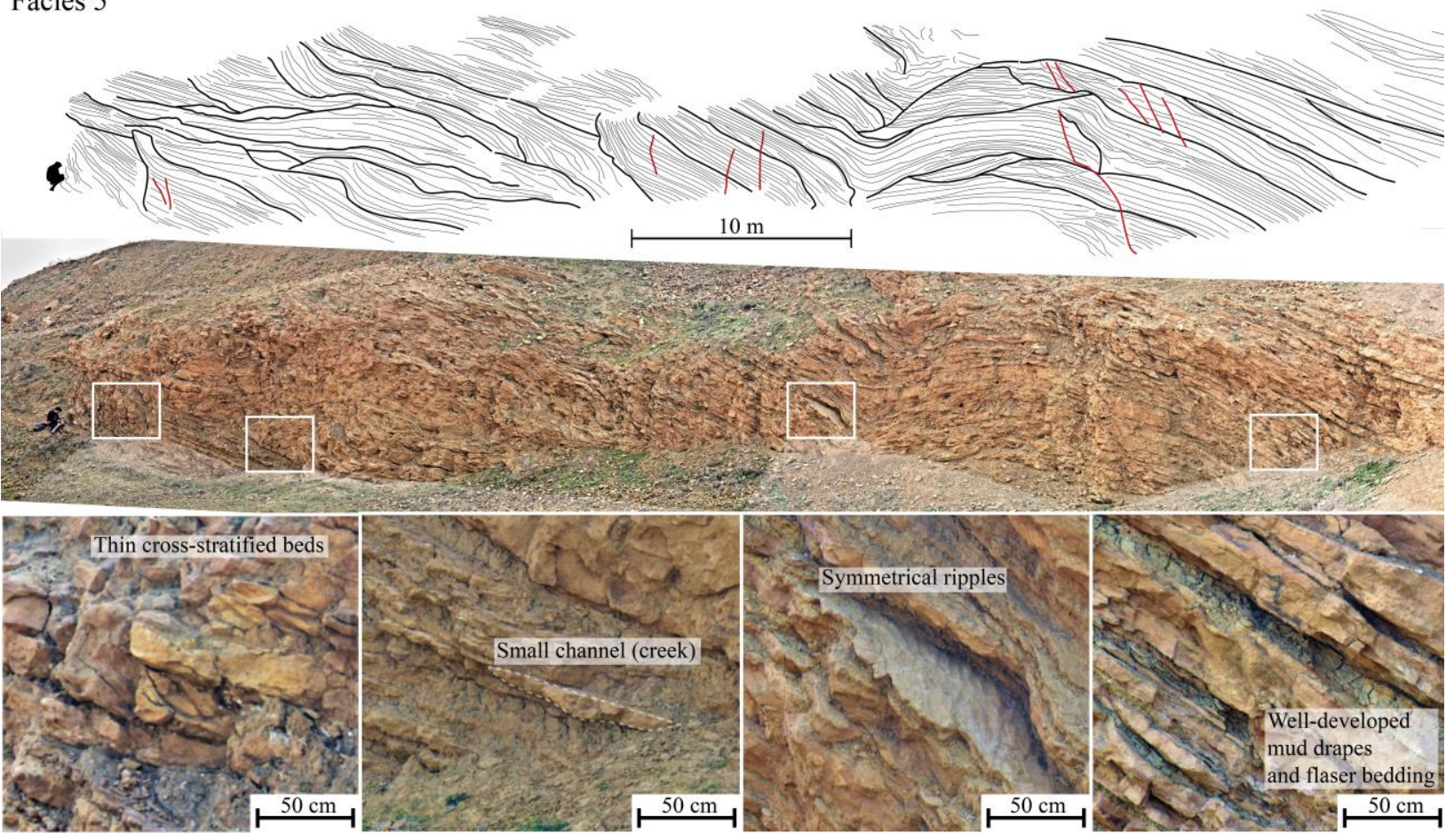


Figure 8. slumped interval of facies 5. Thick black lines are thick mud drapes, separating pack ages of sand sheets. Bottom from left to right: Rare low angle cross-stratified bed. Small $\pm 1 \mathrm{~m}$ wide channel filled with coarse sandstone. Bed showing symmetrical ripples indicating minor wave reworking and low (intertidal) depositional water depth. Well-developed mud drapes and flaser bedding showing rapidly alternating current directions and varying current strengths under the action of tides.

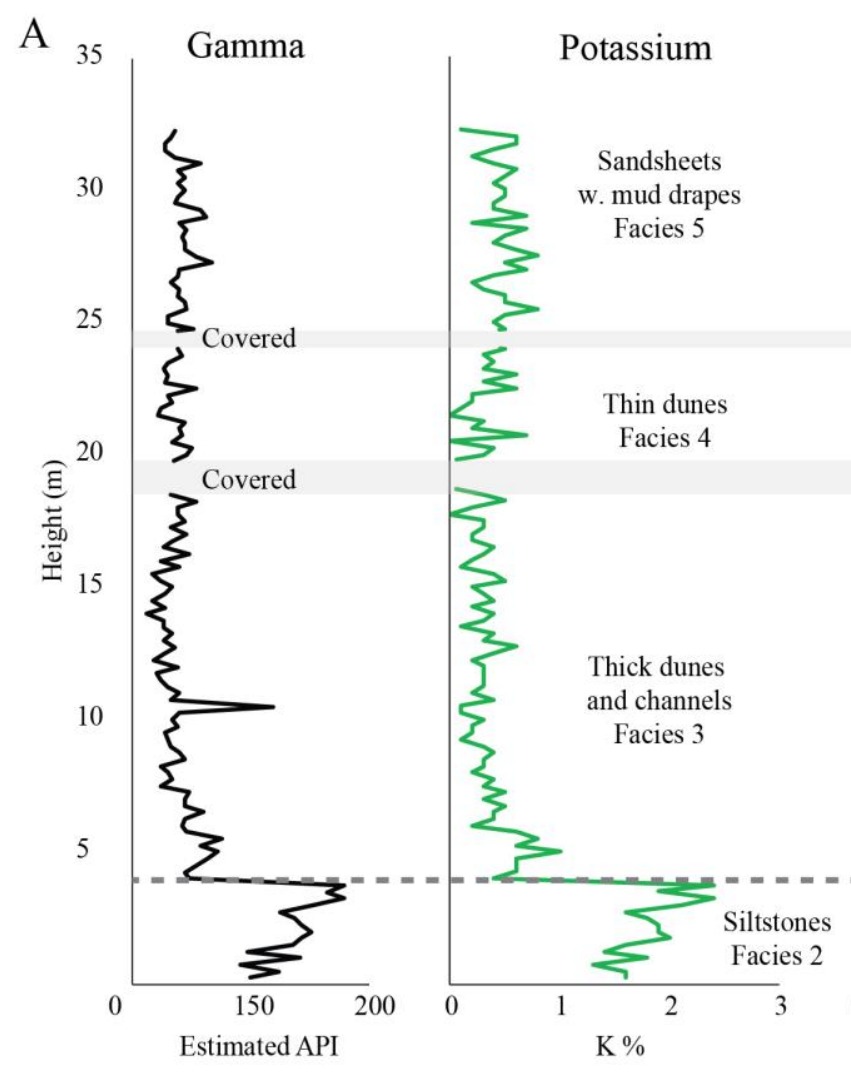

B

K vs Th

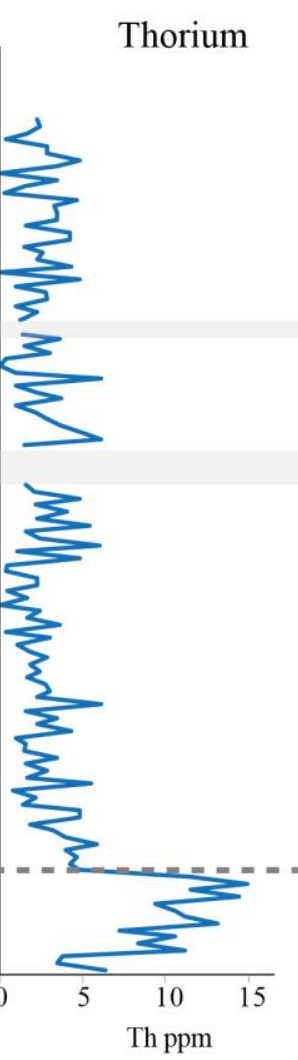

Uranium

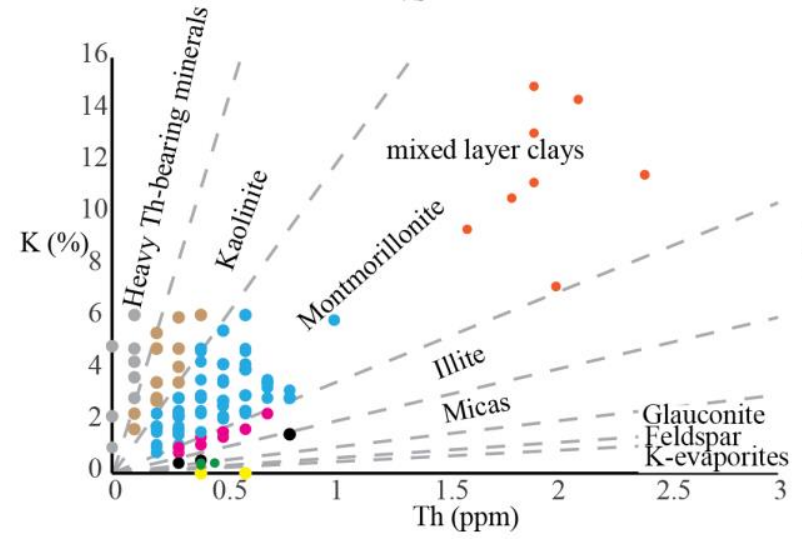

$\mathrm{C}$

$\mathrm{Th} / \mathrm{U}$ vs Th/K

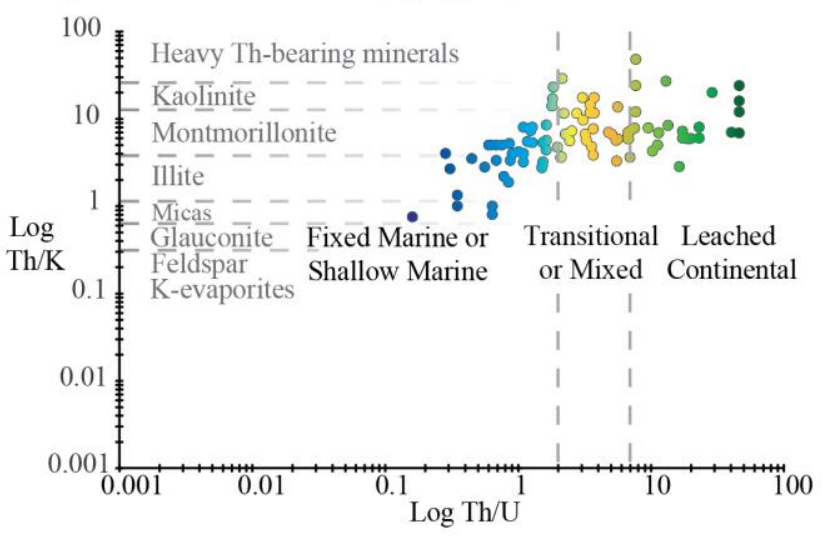


Figure 9. A: Graphs indicating the amount of gamma emission across facies 2-5. Note that fine grained facies 2 has the highest gamma response. Amounts of $K, U$ and Th are also shown. $B . K$ versus Th plot indicating clay mineralogies. Dominant clay types are montmorillonite and kaolinite, which indicate that a large portion of the clay minerals originated from continental weathering. C: Plot showing the ratios between Thorium and Potassium versus Thorium and Uranium. These ratios show the origin of clay minerals present at Ben Allou (Adams and Weaver, 1958; Schlumberger, 2013) and indicate that clays within the sandstones are from a mixed shallow marine/continental source.

\section{INTERPRETATIONS}

\section{Tide-dominated delta}

Facies 1 are very fine grained with no visible sedimentary structures, suggesting a relatively deep setting were settling of sediment is the dominant depositional process. The overlying facies 2 is similar with the exception that these rocks have occurrences of coarse grained, upwards fining beds that are interpreted as turbidites (Bouma, 1964). The common sandy stringers in facies 2 and planar laminated fine grained sediments suggest episodic low density turbidites (or hyperpycnites) as the dominant depositional process with occasional deposition of thicker, coarser grained turbidites (Bouma, 1964; Mulder et al., 2003). The sedimentary structures in the overlying facies (3) include stacked sets of amalgamated dunes, bidirectional current structures, numerous reactivation surfaces and inclined heterolithic stratifications. These features are commonly associated with tidal processes (Davis and Dalrymple, 2011; Longhitano et al., 2012). This is because tidal environments are characterized by rhythmically alternating current strengths and directions, leading to the formation of rhythmic grainsize variations and erosional surfaces of reactivation. Facies 3 has the thickest cross stratified intervals, which are interpreted as tidal dunes (Fig. 4). Strong tidal currents often lead to the development and stacking of coarse grained tidal dunes in relatively shallow water depths where tidal energy is high (Davis and Dalrymple, 2011). Tidal dune thickness has been linked to palaeo water depth suggesting that facies 3 formed in a permanently submerged, subtidal environment (Yalin, 1987). The gradual upwards transition into facies 4 can represent a gradual shallowing in water depth, since facies 4 has much smaller dunes, and more preservation of muddy material in the form of muddy rip up clasts. Facies 5 is interpreted as the shallowest water depth facies, having almost no tidal dunes, and those that are present are relatively thin. Facies 5 is heterolithic, containing many mud drapes and muddy layers. The dominant sedimentary structures here are sand sheets which likely have been affected by a slight amount of oscillatory wave currents as shown by the presence of swales and symmetrical ripples (Figs. 7; 8). Occasional presence of mudcracks can indicate periodic subaerial exposure may have affected the sediments in facies 5.

The low energy, relatively deep marine facies 1 and 2 coarsen upward strongly across a sharp, erosional boundary into facies 3 . This upward coarsening facies trend from a relatively deep water with limited current activity, into a siltstone dominant turbidite-bearing setting and then a coarse 
grained tide-dominated setting is interpreted as reflecting a tide-dominated delta, that formed under gradually shallowing water depth conditions. The sharp erosional boundaries between facies 2 and 3 can signify a lowstand surface of marine erosion, across which a landward facies shift occurred. This landward facies shift coincided with a forward progradation of shallow marine sandstone units belonging to facies 3,4 and 5 which developed over and eroded into the deeper environments (facies 1 and 2).

Tidal environments are usually asymmetric (having a dominance of either the ebb or flow component; Davis and Dalrymple (2011)). However, dominant ebb-tidal palaeocurrents are by far the most common in tidal deposits since sediments are more abundant on the landward sides of the tidal system, so currents originating from the land are more sediment laden and become dominant in the sedimentary record (Davis and Dalrymple, 2011). The dominant southwesterly current direction is thus interpreted to represent the ebb current, which is the direction of deepening or, the basinward direction (Fig. 3; Davis and Dalrymple, 2011). Furthermore, the sandstone units containing facies 3,4 and 5 are not laterally uniform but thin (but not pinch out) towards the northeast. This direction is opposite to the dominant palaeocurrent direction in facies 3 and 4 , which suggests that the landward delta portions where accommodation space is lower, are towards the northeast, while the dominant basinward palaeocurrent is towards the opposing southeast direction. This interpretation implies a northeast/southwest depositional dip trend interpretation for the Ben Allou tide-dominated delta. Despite the fact that the Rifian Corridor had a general eastwest trend, the wider palaeogeographic context can allow for this interpretation, due to the relatively unconstrained erratic coastline arrangement of the Rifian Corridor or, Rifian Archipelago marine zone.

Ratios of $\mathrm{Th} / \mathrm{K}$ and $\mathrm{Th} / \mathrm{U}$ show that clay mineralogies at Ben Allou are consistent with mixed shallow marine and continental sediments (Schlumberger, 2013; Fig. 9C). Based on the same data, montmorillonite is inferred to be the most common clay mineral here, followed by kaolinite (Fig. 9B). The clay sediments are scarce in Illite, glauconite and feldspars. The origin of these clay minerals is interpreted from gamma ray spectrometry data to be from a mixed, shallow marine/continental source (Schlumberger, 2013; Fig. 9C). Based on the intactness of the carbonate debris, it is interpreted that most of the carbonate sediment here is authigenic and from a nearby source area. This shows that these shallow marine deltas were powerful carbonate factories, producing large amounts of carbonate detritus. This material was then mixed with quartz-rich continental sands and clays.

\section{Facies depositional environment interpretations}

\section{Offshore and prodelta (facies 1 and 2)}

The mudstones at the bottoms of the cycles (facies 1) are blue-grey in colour and are similar to the rocks in the 'Blue Marl Formation' or 'Blue Marl Subunit' (Fig. 2; Bernini et al., 2000). The Blue Marl Formation is a regionally abundant rock formation, described as 'open marine marls' by Bernini et al., (2000), and likely represented an island-bearing but mostly submerged shelf system at the southern margin of the Rifian Archipelago (Ivanovic et al., 2013; Beelen et al., 2020). These facies contain small amounts of dark organic matter, which is portrayed as the characteristic bluish 
hue against the grey sediments.

Facies 1 grade into turbidite-bearing rocks belonging to facies 2 . These rocks lack the blue hue and contain no preserved organic matter. The homogenous character and lack of sedimentary structures in facies 2 shows that these sediments also formed in relatively deep water, but the slightly coarser grainsize, presence of turbidites and lack of organic matter are more consistent with a pelagic, inclined, marine environment like a prodelta setting (Rich, 1951).

\section{Distal delta front (facies 3)}

Internal dune and stacked dune architectures are defined by three types of surfaces. These are, from least to most extensive: 1) Cross stratal foresets 2), erosional reactivation surfaces, which can crosscut foresets 3 ), set boundaries, which separate packages of cross stratified sandstones. Cross stratified intervals in facies 3 are interpreted to represent ' $3 \mathrm{D}$ ' tidal dunes (Fig. 4). These are bounded at the top and at the bottom by set boundaries that define 2-4 $\mathrm{m}$ thick dune packages or 'dune sets' whereby each dune set represents a generation of migrating dunes. Muddy and clayey material is entirely absent from facies 3, supporting the notion that that these stacks of dunes formed in the subtidal reaches of the tide-dominated delta, where tidal current energies are too strong and too frequent to allow muddy material to settle in the tens-of-meters thick water column. The common sigmoidal shape of the dune forests indicates that these dunes can be completely preserved, with limited amounts of post-depositional erosion. Commonly however, erosional set boundaries mark the tops of the dunes and signify the erosion of dune topsets when a younger generation of dunes develop on top. Large dunes are often intersected by high-angle sigmoidal reactivation surfaces that partially truncate dune volumes. Stacks of dunes are thus visible as cross stratified, coarse grained sandstones bounded by numerous horizontal and curved reactivation surfaces, and represent the amalgamation of large, overlapping tidal dunes (Fig. 10). Various exposures of the facies 3 sandstones face oblique (Fig. 10B) or perpendicular (Fig. 10C), to the palaeocurrent, and do not show diagonal or sigmoidal cross stratifications. Instead, these exposures are characterised by lens-shaped set boundaries and foresets, that are visible as trough cross stratifications in the outcrop, which is testament to their 3D dune geometry (Figs. 4; 10C). Existing studies like Dalrymple and Rhodes, (1995) and Yalin, (1987) show that depositional water depths for tidal environments can be estimated from dune thicknesses. Some estimates shown that dune height is typically $\pm 17 \%$ of the depositional water depth (Dalrymple and Rhodes, 1995; Allen and Homewood, 1984). Although water depth is not the only control on dune size, this notion suggests that these deepest and most distal sandstone facies developed in a subtidal environment, sitting permanent submerged at an estimated 25-35 m water depth (Fig. 11). The presence of relatively high energy coarse grained dune-bearing architectures and subaqueous channels is most typical of a subtidal delta front environment (e.g. Flemming and Kudrass, 2018). Dune thicknesses in facies 3 are about $10 \%$ of dune widths, these ratios are similar to measured tidal dunes published in Blondeaux and Vittori, (2011). 


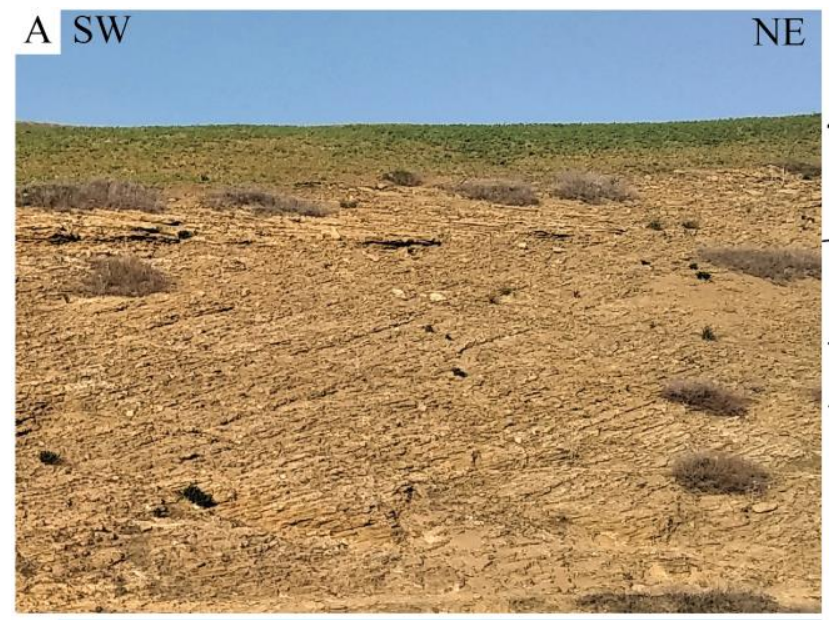

B Exposure is parallel to paleocurrent

C S

$\mathrm{N}$

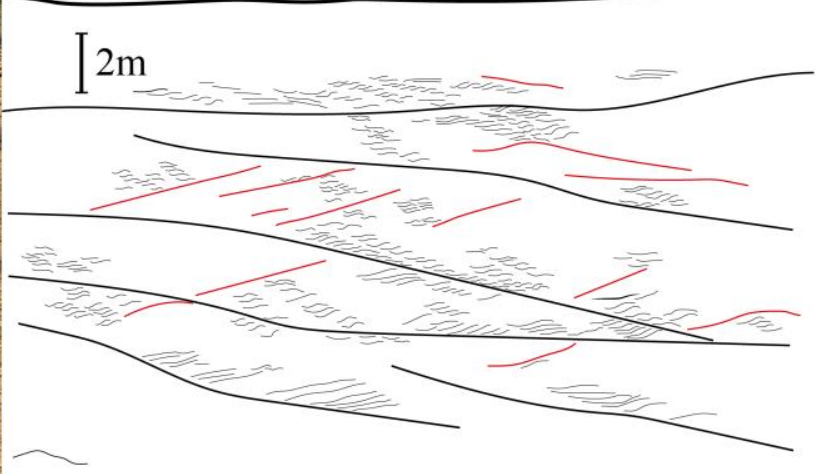

D Exposure is oblique to paleocurrent
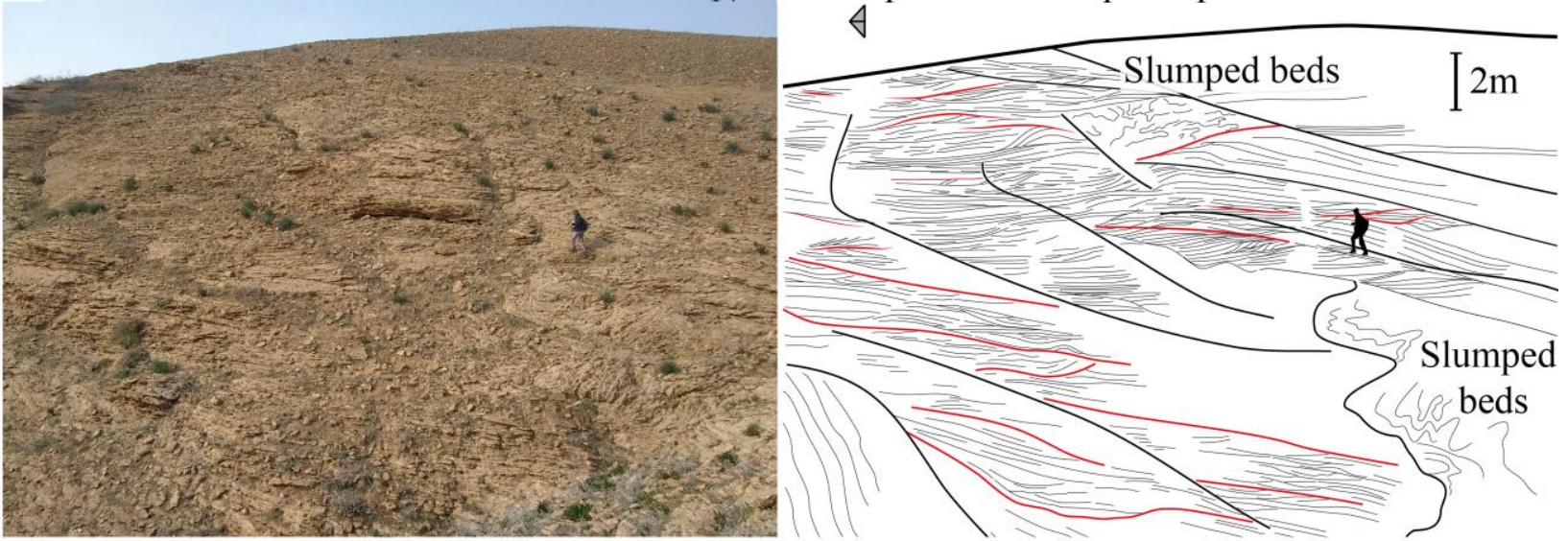

$\mathrm{E} N \mathrm{NW}$

SE

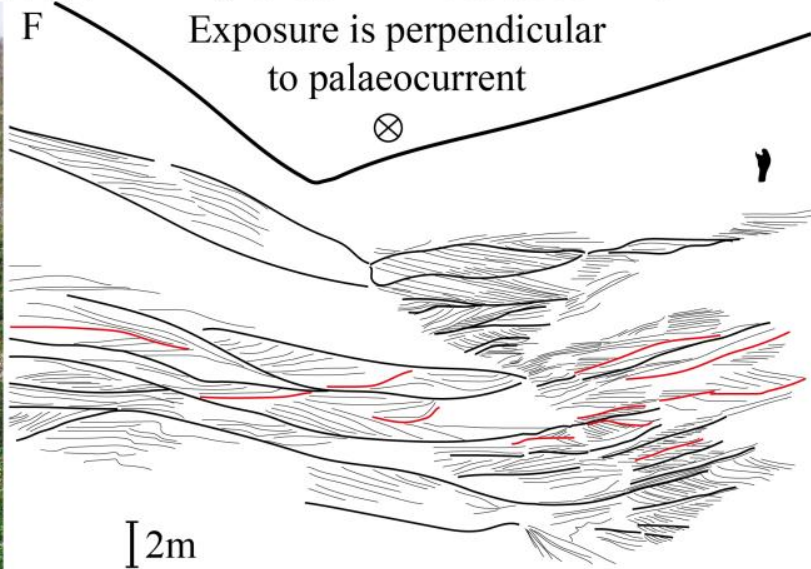

Figure 10. Three interpretation panels of delta front facies, revealing that these portions of the sandstone units are dominated by stacked, cross-stratified dunes. A, B: Interpretation of exposures that trend parallel to palaeocurrent showing straight and sigmoidal cross stratification. $B, C$ : Interpretation of exposures that trend oblique to palaeocurrent. E, F: Interpretation of exposures that trend perpendicular to palaeocurrent showing through cross bedding. Thick black lines are set boundaries that compartmetalise dune sets. Thin black lines are dune foresets. Red lines are reactivation surfaces. 


\section{Proximal delta front (facies 4)}

Facies 4 develops gradually from the underlying facies 3 , and has smaller, thinner stacks of dunes and well as smaller subaqueous channels (Figs. 6; 7). Like in facies 3, mud drapes (a characteristic indicator of tidal systems) are absent here, but the presence of layers of muddy rip up clasts point to the deposition and subsequent erosion of mud drapes and muddy strata. Thinner dunes and fewer channels, as well as slightly more indication of mud deposition, suggest that these facies developed in slightly shallower water depths than facies 3 , where fine grained material has occasionally enough time to settle during slack tide before being winnowed by tidal currents. Based on dune thicknesses, depositional water depth for facies 4 is estimated at 15-25 m (Fig. 11). 0.5-2 m thick tabular cross strata bounded by set boundaries are common in facies 4 . These are interpreted to represent stacks of forward migrating dune sets. Based on architectural interpretations from various outcrops that face towards and oblique to the dominant southwesterly current direction, these dunes are interpreted to be two-dimensional (2D), which may reflect slightly lower deposition energy for facies 4, as compared to facies 3 (Costello and Southard, 1981). Dewatering structures and minor slumping in facies 4 indicate that these sediments may have experienced some occasional destabilization, possibly due to partial dewatering during extreme low tides (Greb and Archer; 2007). The overall similarities with facies 3 , indicates that facies 4 remains part of the subtidal delta front, but based on the 2D, relatively small dune architectures, this facies is interpreted as a having formed in a shallower, more proximal portion of the delta front. 
A Approximate water depth (based on dune thicknesses)

$35 \mathrm{~m}$,

$30 \mathrm{~m}^{\mathrm{I}}$

$25 \mathrm{~m}$

$20 \mathrm{~m}$,

$10 \mathrm{~m}$ ।

$15 \mathrm{~m}$ ।

Subordinate flood current

$5 \mathrm{mi}$

$0 \mathrm{~m}$ ᄂ $-\ldots-\ldots \ldots$ Low tide

Dominant ebb current

Facies 5

Facies 4

Facies 3

Delta plain

Prox. delta front

Distal delta front

-Foreset

- Set Boundary

- Reactivation surface

B
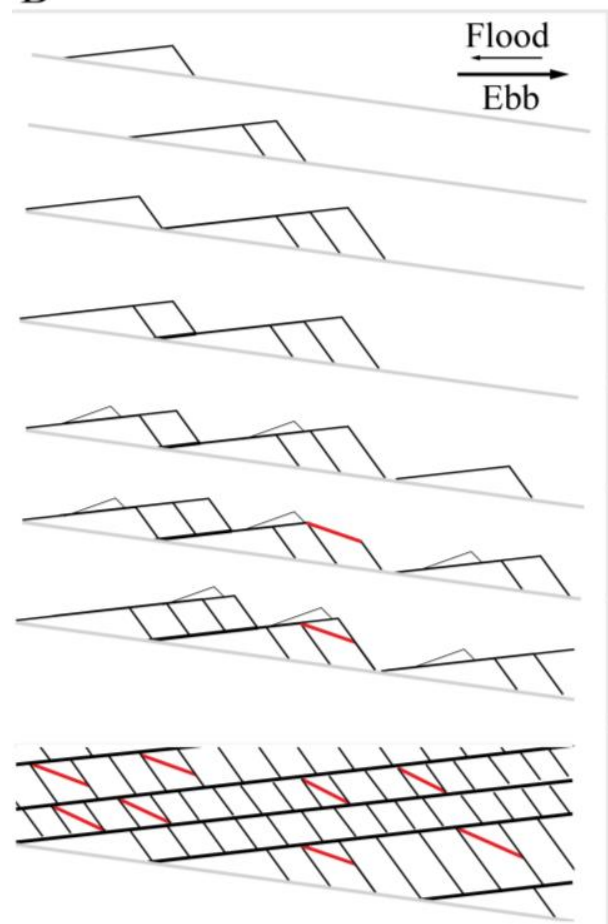

A simple dune migrates along the dominant ebb current

The dune progrades, developing foresets

The dune grows and slows down

Smaller, trailing dunes climb on top of larger, leading dunes

Superimposed bedforms bypass host dunes and develop into leading dunes

Opposing currents erode existing dunes

Erosional surface is healed by sedimentation developing into a reactivation surface

Continuation of these processes develop into the observed stratigraphy

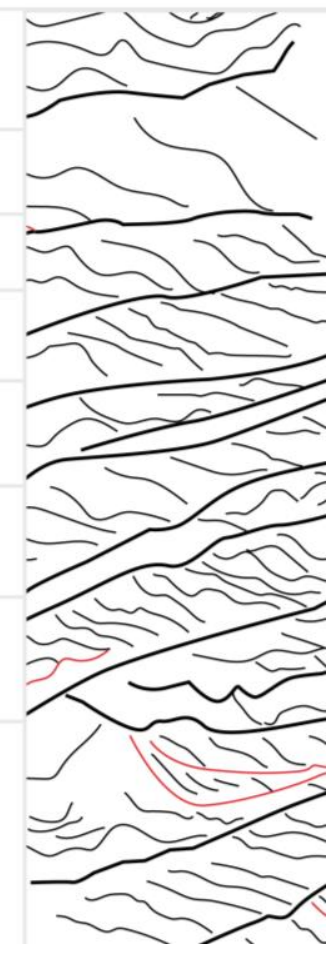

Figure 11. A: Schematic stratigraphic development of the sand sheet and dune architectures observed at facies 3,4 and 5 at Ben Allou, with corresponding high and low tide water depths. Water depths are estimated from dune thicknesses. In the intertidal zone (facies 5), sand sheets and thin dunes dominate; these are gradually replaced with stacked dunes near the delta front (facies 3 and 4). Channel architectures are omitted in this model. B: schematic model for dune migration and development of dune-bearing stratigraphy. Dunes move basinward down a depositional ramp under the action of dominant southwesterly ebb currents. Schematic trace of 
observed stratigraphy shows correspondence to the theoretical model. Photo of traced stratigraphy is in figure 7, thin lines are dune foresets, thick lines are set boundaries and red lines are reactivation surfaces.

\section{Delta plain (facies 5)}

Facies 5 is dominated by tabular sand sheets that are separated by mud drapes. These upper portions of the tide-dominated delta succession have the most significant grainsize variations, containing rapidly alternating layers of sand and clay. In this facies, clayey intervals occur as thin mud drapes or less commonly, as flaser bedding and muddy layers. Thin cross stratified layers are sometimes present and indicate that this facies has the smallest dunes and likely a shallow depositional water depth of 0-15 m. Extensive preservation of mud drapes and flaser bedding supports this and suggest that these facies formed in an intertidal environment (Allen and Homewood, 1984; Desjardins et al., 2012). Facies 5 also has minor indication of wave action in the form of rare hummocks and swales and symmetrical ripples (Fig. 8; 9). Because of these observations, the depositional environment for facies 5 is interpreted as an intertidal delta plain, where periodic quiescence of tidal currents during slack tide allows for the development of muddy strata (Desjardins et al., 2012). Since tidal energy typically decreases towards the coast, this observation corroborates the notion that the facies 5 delta plain represent the shallowest and most proximal sedimentary portions of the exposures at Ben Allou (Davis and Dalrymple, 2011).

Facies 5 has the most slumping. In some cases, 5-10 m thick intervals have been extensively slumped and deformed (Fig. 8). Sediment bodies in these intertidal environments were likely more prone to destabilization due to the occurrence of periodic desiccation events at low tide (Greb and Archer; 2007). Even though facies 5 has the finest minimum grain size, sandstone remains the dominant lithology, thus indicating that the Ben Allou delta systems may not have preservation of mud flat environments, which are typically common in proximal tide-dominated environments. Instead, powerful, amplified tidal currents in the sea strait depositional setting prohibited the preservation of extensive muddy strata and resulted in the development of sand sheet dominated deposits with occasional mud drapes instead.

\section{Ichnology}

There are significant differences in ichnofacies assemblages between the proximal and distal facies of the tide-dominated deltas. Facies 1 has only small Chondrites trace fossils and preservation of organic matter, suggesting that these shelfal sediments formed in dysoxic environments, with limited amounts of benthic activity (Rhoads, 1975). Ichnofossils in facies 2 remain sparce, with the exception of some bivalve casts. The sandstone units (facies 3,4 and 5) have abundant ichnofossils, which vary significantly, suggesting a well oxygenated environment (Rhoads, 1975). Ichnofossil variations across the various delta environments are likely due to changes in current intensity (Maceachern et al., 2005; Gani et al., 2009) and more importantly, changes in the rigidity of the sedimentary substrate (Kaust and Bromley, 2012). The subtidal facies ( 3 and 4) mostly has 
ichnogenera that are associated with soft substrate burrowing like Thalassinoides and Scolicia (Fig. 12; Kaust and Bromley, 2012). In these portions of the sandstones, the overall ichnofacies remain most consistent with soft substrate Cruziania ichnofacies. The intertidal delta plain facies (5) has many borings and surface grazing ichnogenera like Psilonichnus and Rhizocorallium, indicating a more rigid substrate, (Fig. 12; Pemberton and Frey, 1984; Pemberton and Wightman, 1992; Maceachern et al., 2005; Gingras and MacEachern, 2012; Kaust and Bromley, 2012). Ichnofossils in the proximal delta plain (facies 5) are consistent with a firm substrate Glossifungites ichnofacies, suggesting that these sediments were rigid and may have been subject to evaporation in the intertidal zone (Fig. 12; Buatois et al., 2012).
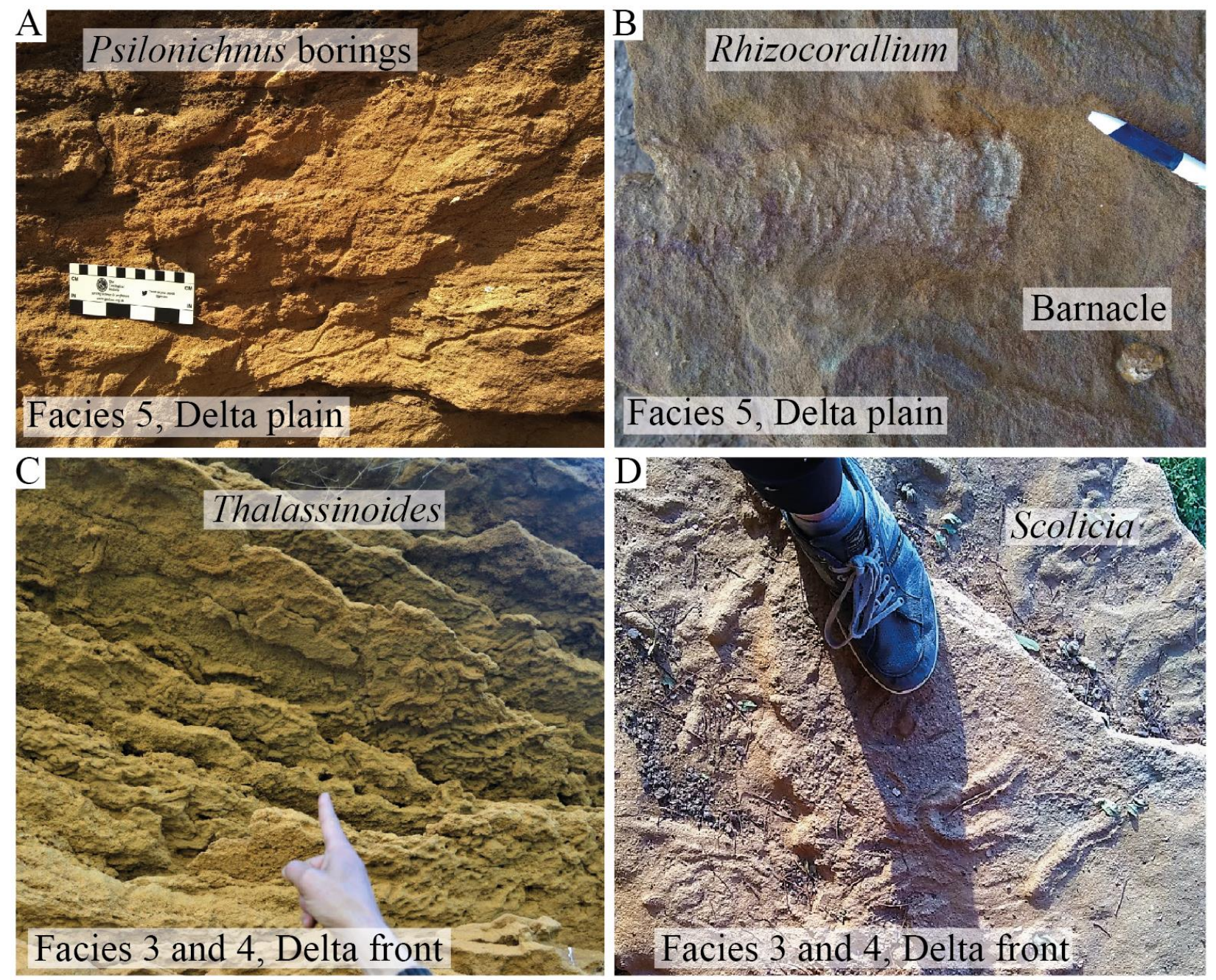

Figure 12. Photos of Ichnofossils at Ben Allou. A, B: Facies 5 (intertidal delta plain) trace fossils are associated with borings $(A)$ and surface grazing $(B)$ suggesting firmground palaeo substrate and Glossifungites ichnofacies. Note barnacle fossil with slight scouring surrounding it, 
suggesting in situ deposition. C, D: Facies 3 and 5 (subtidal delta front) trace fossils which are associated with softground horizontal burrow networks and Cruziana ichnofacies.

Table 1. Five facies and facies interpretations exposed at Ben Allou

\begin{tabular}{|c|c|c|c|c|c|}
\hline & $\begin{array}{l}\text { Facies 1: } \\
\text { Claystones }\end{array}$ & $\begin{array}{l}\text { Facies 2: } \\
\text { Siltstones }\end{array}$ & \begin{tabular}{|l} 
Facies 3: \\
Thick cross \\
stratified \\
sandstones
\end{tabular} & $\begin{array}{l}\text { Facies 4: Thin } \\
\text { cross } \\
\text { stratified } \\
\text { sandstones }\end{array}$ & $\begin{array}{l}\text { Facies 5: } \\
\text { Sand sheets }\end{array}$ \\
\hline Interpretation & $\begin{array}{l}\text { Offshore } \\
\text { (shelf) }\end{array}$ & Prodelta & Distal delta front & $\begin{array}{l}\text { Proximal delta } \\
\text { front }\end{array}$ & Delta plain \\
\hline Bedform type & None & None & $\begin{array}{l}\text { 1.5-4 m thick } \\
\text { dunes }\end{array}$ & $\begin{array}{l}0.5-1.5 \mathrm{~m} \\
\text { thick dunes }\end{array}$ & sand sheets \\
\hline $\begin{array}{l}\text { Mean bedform } \\
\text { grainsize }\end{array}$ & Clay & Silt & $\begin{array}{l}\text { Medium-coarse } \\
\text { sand }\end{array}$ & Medium sand & Medium sand \\
\hline $\begin{array}{l}\text { Set boundary } \\
\text { grainsize }\end{array}$ & - & L & Fine sand & $\begin{array}{l}\text { Fine sand } \mathrm{w} \text {. } \\
\text { muddy clasts }\end{array}$ & Clay \\
\hline Channels & None & None & $\begin{array}{l}15-120 \mathrm{~m} \text { wide } \\
\text { channels filled } \\
\text { with cross } \\
\text { stratified coarse } \\
\text { sand }\end{array}$ & $\begin{array}{l}5-15 \mathrm{~m} \text { wide } \\
\text { channels filled } \\
\text { with cross } \\
\text { stratified } \\
\text { medium sand }\end{array}$ & $\begin{array}{l}\text { Small } 1-2 \mathrm{~m} \\
\text { wide creeks }\end{array}$ \\
\hline Bedform size & None & None & Large & Intermediate & Small \\
\hline $\begin{array}{l}\text { Palaeoconsistency } \\
\text { (based in } \\
\text { ichnology and } \\
\text { sedimentary } \\
\text { structures }\end{array}$ & Soft & Soft & $\begin{array}{l}\text { Loose, } \\
\text { permanently } \\
\text { submerged }\end{array}$ & $\begin{array}{l}\text { Loose but } \\
\text { maybe } \\
\text { occasionally } \\
\text { dewatered }\end{array}$ & $\begin{array}{l}\text { Firm and } \\
\text { frequently } \\
\text { dewatered }\end{array}$ \\
\hline $\begin{array}{l}\text { Estimated } \\
\text { Depositional } \\
\text { water depth } \\
\text { (based on fossil } \\
\text { evidence and dune } \\
\text { thicknesses) }\end{array}$ & $50-80 \mathrm{~m}$ & $35-50 \mathrm{~m}$ & $25-35 \mathrm{~m}$ & $15-25 \mathrm{~m}$ & $0-15 \mathrm{~m}$ \\
\hline
\end{tabular}




\begin{tabular}{|l|l|l|l|l|l|}
\hline Processes & $\begin{array}{l}\text { Settling of } \\
\text { sediment }\end{array}$ & $\begin{array}{l}\text { Low and high } \\
\text { density } \\
\text { turbidity } \\
\text { currents and } \\
\text { settling of } \\
\text { sediment } \\
\text { fluvial influence }\end{array}$ & $\begin{array}{l}\text { Tides and } \\
\text { minor fluvial } \\
\text { influence }\end{array}$ & $\begin{array}{l}\text { Tides with } \\
\text { minor wave } \\
\text { reworking, } \\
\text { minor fluvial } \\
\text { influence }\end{array}$ \\
\hline $\begin{array}{l}\text { Palaeocurrent } \\
\text { strength }\end{array}$ & Very low & Very low & High & Intermediate & Low \\
\hline $\begin{array}{l}\text { Variation in } \\
\text { palaeocurrent } \\
\text { directions }\end{array}$ & N/A & N/A & Medium & Low & High \\
\hline Characteristics & $\begin{array}{l}\text { Lacking } \\
\text { sedimentary } \\
\text { structures and } \\
\text { presence of } \\
\text { organic } \\
\text { matter }\end{array}$ & $\begin{array}{l}\text { Mostly } \\
\text { lacking } \\
\text { sedimentary }\end{array}$ & $\begin{array}{l}\text { Curved } \\
\text { reactivation } \\
\text { surfaces }\end{array}$ & $\begin{array}{l}\text { Dewatering } \\
\text { structures and } \\
\text { minor } \\
\text { slumping. }\end{array}$ & $\begin{array}{l}\text { Intervals of } \\
\text { major } \\
\text { slumping and } \\
\text { syn- } \\
\text { sedimentary } \\
\text { faulting }\end{array}$ \\
\hline $\begin{array}{l}\text { Mud drapes } \\
\text { and flaser } \\
\text { bedding. }\end{array}$ \\
\hline
\end{tabular}




\section{DISCUSSION}

\section{Compound dunes}

Compound dunes are large dunes with smaller bedforms superimposed, and are relatively common in tidal environments, where they can develop into complex stratigraphic architectures (Olariu et al., 2012). Observations of the various preserved dune architectures at the Ben Allou delta front facies (3 and 4), show that compound dune and 'simple' dune architectures are not substantially different in the sedimentary record at Ben Allou. Due to the larger relative surface areas of smaller dunes, these tend to move faster than larger dunes in the same current environment (Liu et al., 2005). Migrating small dunes that superimpose larger developing dunes therefore bypass these, which results in the deposition of sediment in the front of the existing larger dune (Fig. 11A). This material can then develop into a forward dune, and subsequent dune migration and deposition occurs on the backward facing stoss-side of this forward dune. Stratigraphy is built when younger dunes climb on top of an evolving set of existing dunes. This leads to a stacking of dune sets and the observed stratigraphic architectures with steep foresets and shallowly rising set boundaries (Fig. 13). Compound dunes are therefore not preserved as such at Ben Allou and are shown in the stratigraphy as 'simple' stacks of cross stratified intervals (Figs. 7; 11). Numerous reactivation surfaces form throughout this process due to temporarily opposing erosional currents, as well as erosion of older dune sets from superimposition and incision by younger dunes (Davis and Dalrymple). Oblique migration of eroding younger dunes can sometimes develop curved reactivation surfaces. Although reactivation surfaces can be oriented downwards, set boundaries require a positive angle of climb to develop and preserve stratigraphy. Therefore, set boundaries tend to be oriented upwards or, less commonly, at a downwards angle that is lower than the angle of the depositional surface.

From a lithological perspective, dune foresets and set boundaries tend to have significantly finer sands and silts than the surrounding beds, which are mostly medium to coarse sands. Especially the delta plain (facies 5) and proximal delta front facies (4), can have mud drapes and layers of muddy rip up clasts at the bottoms of dune sets, which can represent substantial fluid barriers. Reactivation surfaces sometimes contain finer material but commonly lack any meaningful lithological definition. Due to the lithological significance of foreset and set boundary surfaces, resolving dune architectures can be important for modelling rock properties and rock property distributions in tidal systems. The $50 \mathrm{~cm}$ resolution gamma ray measurement of the various sandstone facies at Ben Allou delta show that the minor gamma-ray emission variations that occur in these sandstones appear as generally random, and fossil bedform architectures that can be observed in the outcrops, cannot be resolved from this type of measurement (Fig. 9A). 
A Vertical exaggeration: 10x
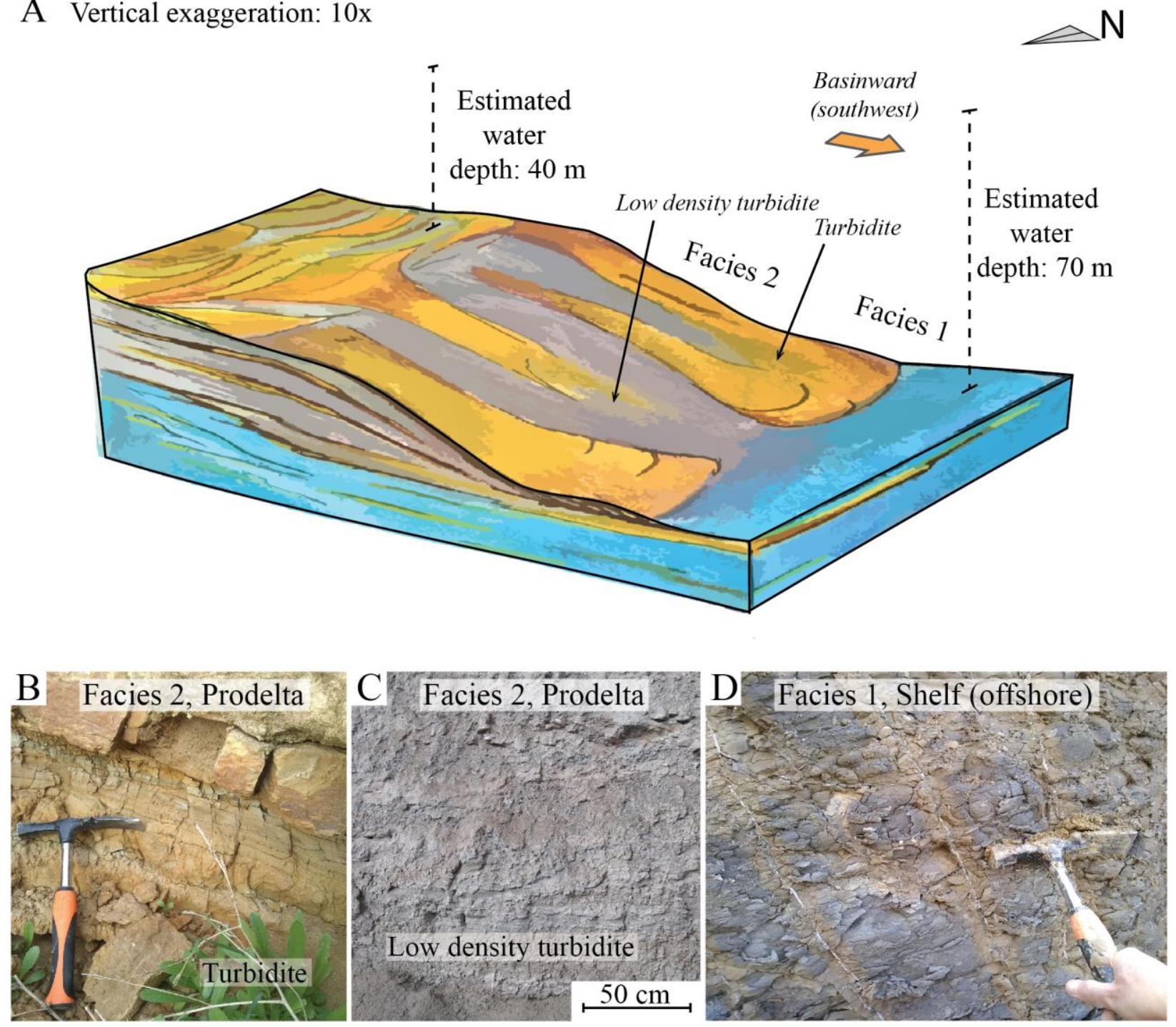

Figure 13. A: Schematic diagram of the fine grained delta portions (prodelta and offshore) of strait-adjacent tide-dominated deltas at Ben Allou (vertical exaggeration is 10x). Prodelta consists of fine grained low density turbidites and coarser grained turbidites Shelf deposits are comprised of homogenous, organic-matter-bearing silty claystones similar to the regionally extensive 'Blue Marl Formation' (Bernini et al., 2000). B, C and D: Photos of the various siltstone and claystone facies demonstrate correspondence to the diagram in $A$.

\section{Fluvio-continental linkages}

The observed arrangement of large channels in the distal delta front and smaller channels in the more proximal delta front and delta plain at Ben Allou is analogous to many modern tidedominated systems. For example, the central portions Ganges-Brahmaputra delta show this channel arrangement, as well as the giant Fly River delta in Papua New Guinea and some smaller 
strait-adjacent deltas at Haraye Khamir in Iran (Fig. 15A; 15B). Finally, such channel arrangements are also observed at tide-dominated deltas like those near Shoal Point, on the northeastern coast of Australia (Fig. 15C). These small tide-dominated deltas are effectively straitadjacent as they face the shallows of the Great Barrier Reef (0-5 m water depth) which is located roughly $80 \mathrm{~km}$ seaward. The strait-adjacent shoreline of northeastern Australia has many such strait-adjacent tide-dominated deltas, which often show an arrangement of sparce channels on the delta plain and more numerous channels in the delta front, as well as small, short hinterland drainages and dunes that increase in size towards the basin. In some cases, substantial deltas in this area can lack fluvial input almost entirely, suggesting that a significant portion of the sediments in these systems is derived from the sea or produced in situ. Like these details, the basinward portions of the deltas at Ben Allou are dominated by channels, which are sometimes amalgamated into channel complexes (Figs. 5; 14). Furthermore, due to the high proportion of shallow marine fossiliferous biogenic carbonate at Ben Allou, the majority of the material here is likely authigenic. Despite this, admixture of quartz-rich detrital sediments, (20-40\%), as well as garnets and continentally derived clays (Fig. 10C) does indicate that some material was provided from landward fluvial sources at Ben Allou. Fluvio-continental linkages therefore likely existed close to the area of deposition but may have been eroded and obscured by more powerful wave and tidal processes. Alternatively, fluvio-continental linkages may simply not be present within the locations of the Ben Allou exposures.

Although no conclusive provenance data exist here, landward derived sediments most likely originated from the Meseta foreland and the southwestern foothills of the Middle Atlas Mountains (Capella et al., 2017), both of which sat at a relatively short distance $(<100 \mathrm{~km})$ from the Rifian Corridor during the Miocene. This close proximity between sediment source and sink can further explain why the detrital quartz fraction is minor and contains immature, euhedral quartz grains and euhedral garnets. 
A Strait-adjacent tide-dominated delta, Miocene Rifian Corridor, Ben Allou, Morocco Vertical exaggeration: 10x Low-tide coastline

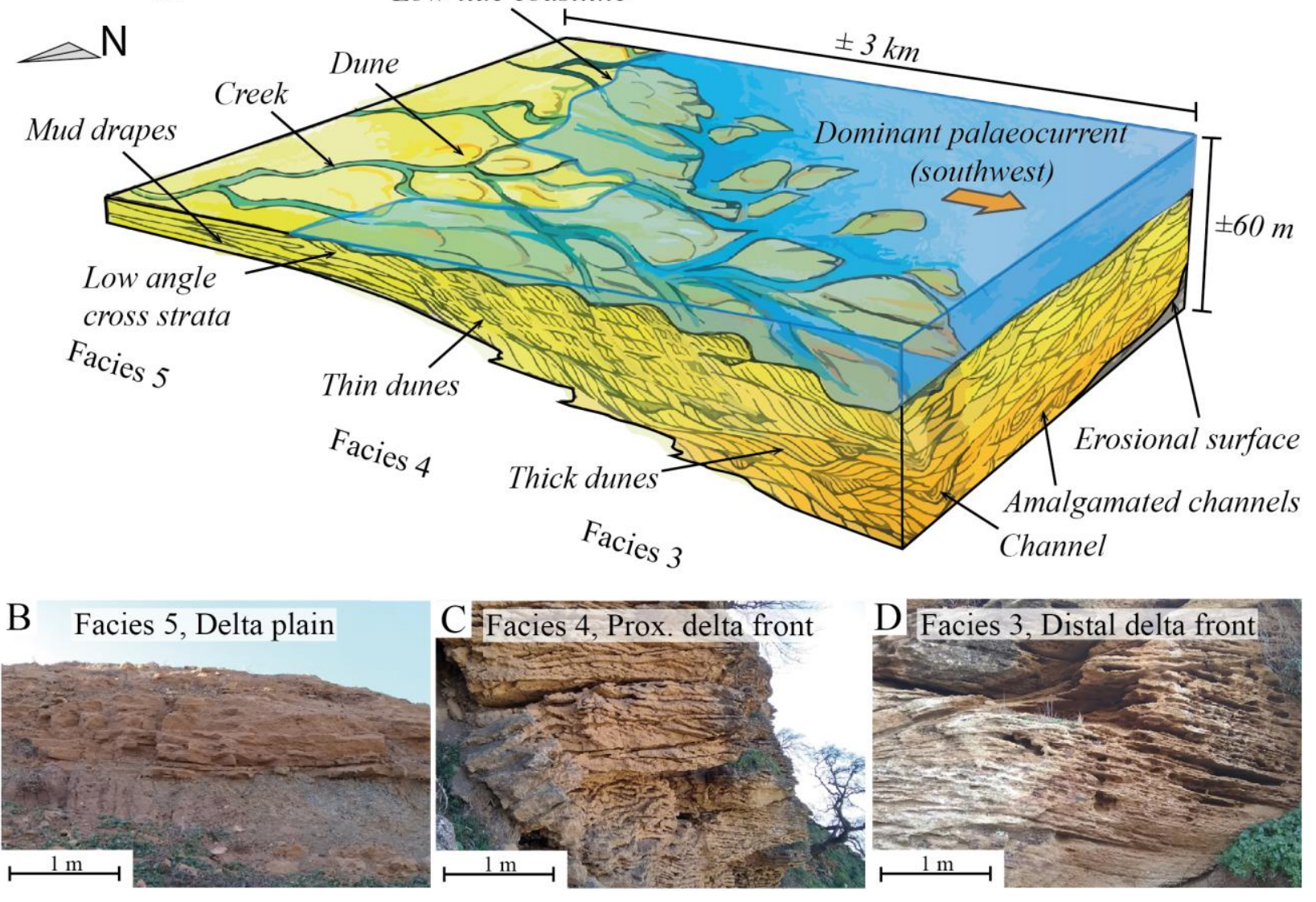

Figure 14. A: Schematic diagram of the sandy portions (delta plain and delta front) of straitadjacent tide-dominated deltas at Ben Allou (vertical exaggeration is $\pm 10 x$ ). Proximal architectures are periodically submerged (intertidal) sand sheets with mud drapes and rare, small channels. Delta front architectures consist of subtidal stacked dunes. B, C and D: Photos of the various sandstone facies demonstrate correspondence to the diagram in A. 


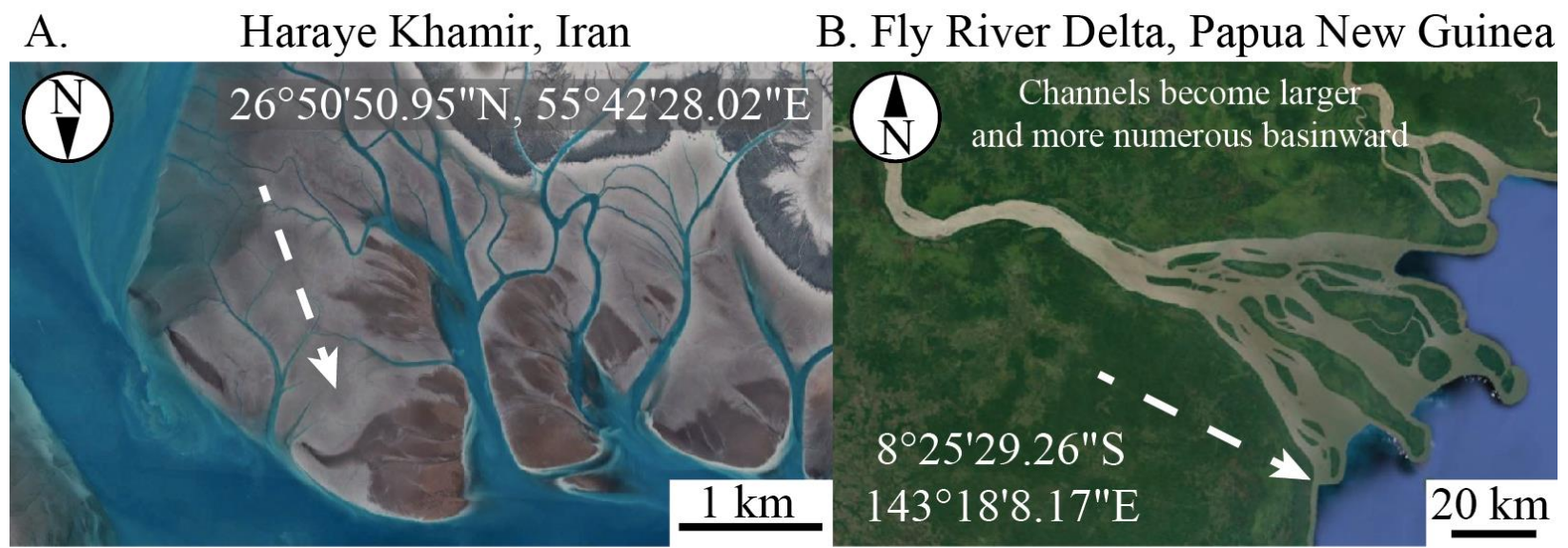

C. Shoal Point, Australia

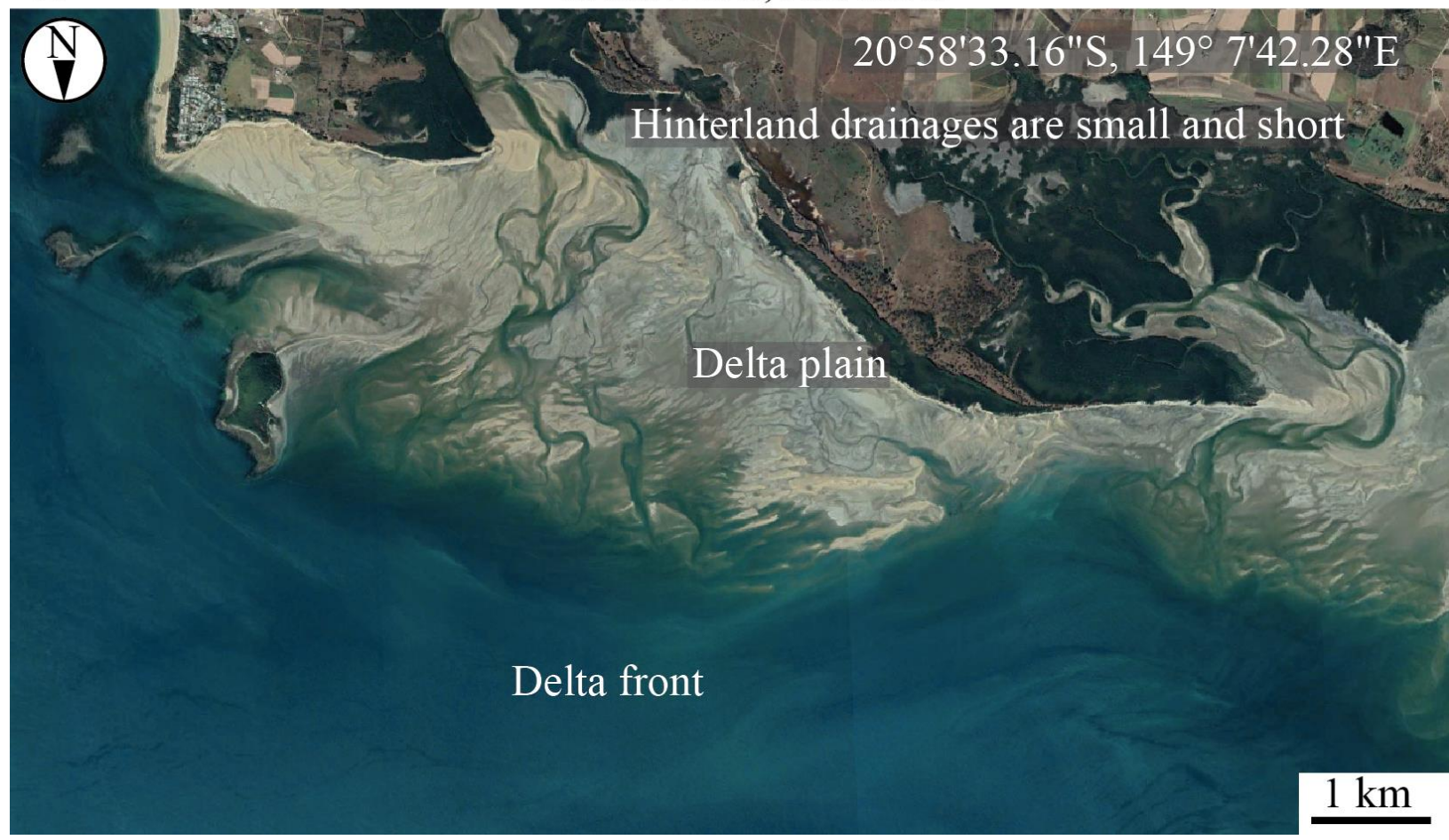

Figure 15. Three possible modern analogies of the Ben Allou. A: Haraye Khamir in Iran shows exposed delta plains with channels that become thicker towards the basin. B: the Fly river Delta in Papua New guinea shows a similar channel geomorphology. C: The best modern analogue for Ben Allou, a strait-adjacent tide-dominated delta at Shoal Point Australia. This delta has more numerous channels in the distal portion of the delta, dunes that increase in size towards the basin and small, short hinterland drainages. 


\section{Delta or estuary?}

Despite the limited amount of external fluvial influences, some of the observed characteristics of the Ben Allou deposits could be associated with an estuarine setting. Examples are the large, erosional boundaries below the sandstones and the dynamic stratigraphic architectures in the sandstone facies (Dalrymple and Rhodes, 1995). However, the facies development at Ben Allou show an evolution from relatively deep, distal delta facies 1 and 2, to progressively shallower and more proximal facies 3 to 5. This indicates that the overall movement of the tide-dominated delta system was progradational, thus defining it as a regressive depositional trend that is associated with deltaic environments (James and Dalrymple, 2010).

\section{Tidal strait versus strait-adjacent tide-dominated delta}

Based on the thicknesses of the dunes and channel forms, the tidal energy is interpreted to be high and the palaeotidal range to be macrotidal $(>4 \mathrm{~m}$ ) at Ben Allou. Accurate palaeotidal range reconstructions are hard to derive from the stratigraphy, but measurements of cross-sectional channel geometries, provide a tentative estimate that corroborates a macrotidal $>4 \mathrm{~m}$ palaeotidal range for the facies 3 at Ben Allou (Devries Klein, 1971; Beelen et al., 2020). Although uncommon in open marine coastal areas, macrotidal ranges are common in sea straits, where the tidal prism is amplified (e.g. Longhitano et al., 2012). This forces the tidal prism into a narrowing strait or archipelago geometry which also amplifies current velocities in the deeper regions of the strait, occasionally giving rise to deep, high-energy depositional environments like the dune bedded strait zone or the strait-center zone sensu Longhitano (2013). Such confined tidal strait systems can have a symmetric facies arrangement, with the strongest currents in the strait center zone, and a gradual decrease in current strength away from this point of maximum tidal energy. However, based on the sedimentary structure and sediment grainsize observations at Ben Allou, it can be inferred that the fine grained distal portions of the succession (facies 1 and 2) formed in a far lower depositional energy setting as compared to the coarse grained tidal environments (facies 3, 4 and 5). This is likely because most of the existing models of strait center zone deposits are derived from deposits that formed in more confined, narrower settings, (e.g. the Messina strait and San Francisco Bay, Longhitano et al., 2012). In contrast, studies on the Rifian Corridor's relatively broad structural setting and palaeogeography, shows that it was a proportionally wide $(50-80 \mathrm{~km}$ according to Capella et al., 2017) continental-scale strait system, making the Rifian Corridor more akin in scale to the modern Gibraltar Strait. The strait-adjacent depositional system at Ben Allou is therefore different from a 'true' confined tidal strait deposit, but may have many similarities with more conventional tide-dominated delta facies models (e.g. Legler et al., 2013; Fig. 16). Concretely, three aspects that confined tidal strait deposits have but are lacking in strait-adjacent delta systems are 1) a symmetrical facies arrangement with regards to the strait centre. 2) A basinward increase in coarse grained facies, and lack of fine grained prodelta and shelf facies. 3) A general lack of channel-bearing facies (although this may not always be the case). Strait-adjacent, tide-dominated deltas are thus more similar to a 'conventional' tide-dominated delta in terms of facies arrangements, with some exceptions that are related to sea strait tidal amplification processes. For 
example, studies on the sedimentary fill of the $\pm 1.000 \mathrm{~km}$ wide Cretaceous Wester Interior Seaway show that some important aspects of standardised sea strait models also exist on far larger scales (Longhitano and Steel, 2017). Notably, propagation of the tidal prism through the sea strait has been shown to bring about a rearrangement in tidal current directions with regards to the orientation of the shoreline (Longhitano and Steel, 2017). This tidal current deflection typically pushes tidal currents to move parallel too or, along the coastline, as compared to tidal currents in open marine settings, which move perpendicular to or, across the coastline (Davies and Dalrymple, 2011). In strait-adjacent deltas that are subject to a strong tidal deflection during progradation, the palaeocurrent pattern can record a progressive upwards-rotatory trend, gradually changing from a shore-perpendicular direction to a shore-parallel palaeocurrent direction (Longhitano and Steel, 2017). Palaeocurrent and channel orientation measurements across various intervals of the sandstone units at Ben Allou indicate a similar pattern. Whereas the lower portions of the sandstones (facies 3 and 4) trend dominantly southwest, there is an approximately $90^{\circ}$ shift in palaeocurrents and channel orientations towards the top of the outcrop in facies 5 (Fig. 5). Therefore, there are various aspects that are characteristic of strait-adjacent deltas but may not be present in conventional tide-dominated deltas. These are: 1) proportionally large delta front facies containing thick intervals of coarse grained dune and channel bearing facies, 2) Upward rotary palaeocurrent trends, associated with continual progradation of the delta system and a gradual increase of the alongshore tidal currents. 3) a relative lack of sedimentary structures associated with waves which reflects a sheltered setting where wind fetch is limited. 4) Relatively sandy delta plain facies and an absence of muddy tidal flats. Sandstone rich delta plains have been observed before in strait-adjacent deltas (Longhitano and Steel, 2012), but the delta plain facies at Ben Allou appear to be particularly sandstone rich. Three possible explanations for the unusually sandy delta plains facies at Ben Allou are: 1) recent weathering and dissolution of the muddy carbonate clays material by meteoric waters; 2) ancient winnowing of the fine grained sediments due to powerful, amplified tidal currents; and/or 3) ancient winnowing of fine grained material in the delta hinterland due to wind processes (Rivers et al., 2020). This confluence of factors may be relatively common in strait-adjacent tide-dominated delta sediment bodies, which indicates that, depending on local depositional conditions, delta front deposits in these settings can be expected to contain widespread, continuous sandstone bodies. 


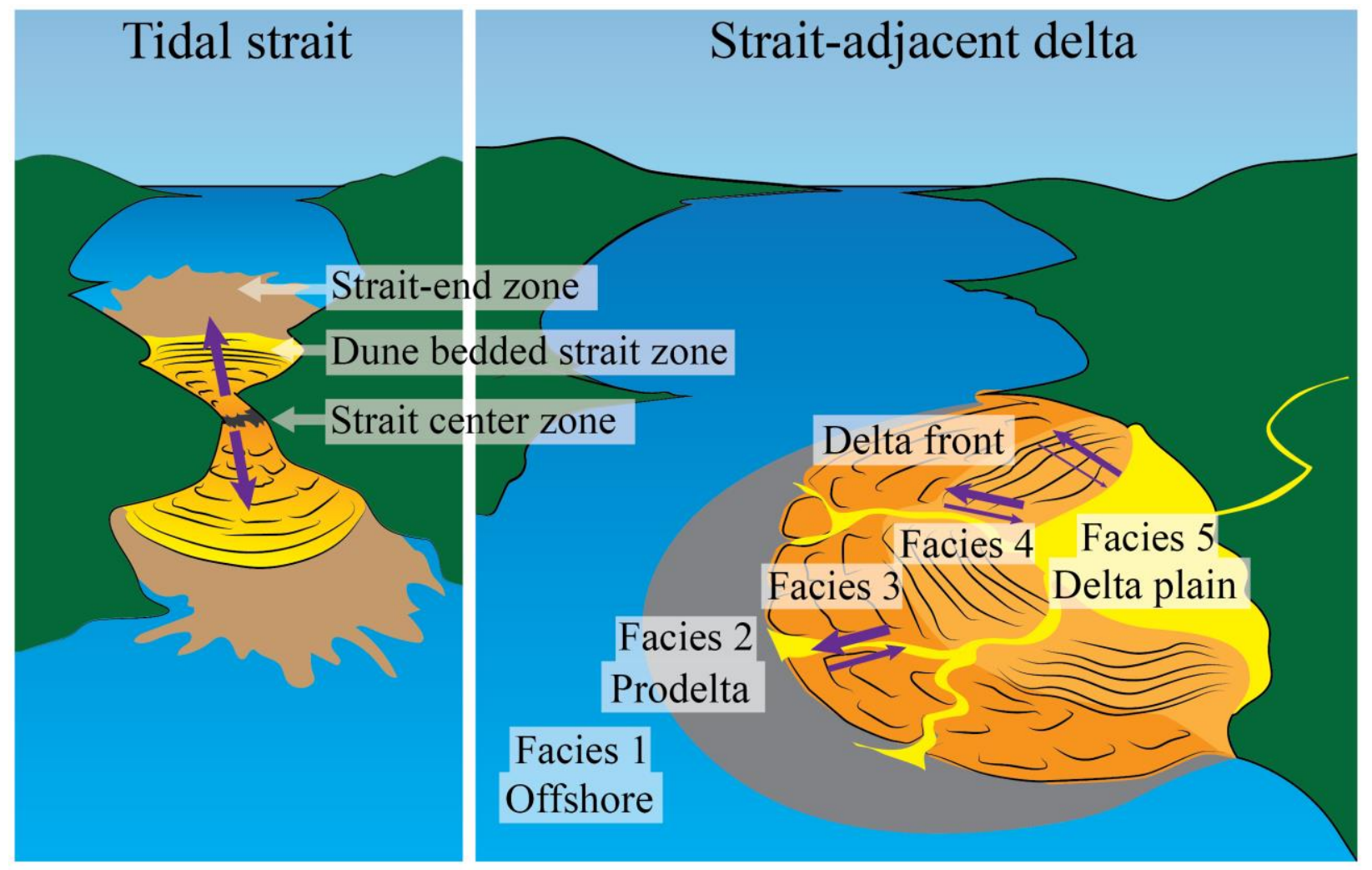

Figure 16. Schematic comparison between a confined tidal strait model (sensu Longhitano, 2013) and a strait-adjacent delta model (this study and Longhitano and Steel, (2012)). Purple arrows show current directions. Thicker arrows show dominant current, thin arrows show subordinate currents.

\section{CONCLUSIONS}

Kilometre-scale exposures of strait-adjacent, tide-dominated deltas deposited in the late Miocene Rifian Corridor expose a gradual development from proximal sand sheets with mud drapes to distal channels and dunes in the delta front, and then deeper depositional water depth prodelta siltstones and open marine claystones. Analysis of dune-bearing architectures in the delta plain and delta front facies at Ben Allou reveals the formation and stacking of various dune and channel bearing architectures. This shows that multiple generations of compound tidal dunes can be recorded as stacks of 'simple' dune sets with many reactivation surfaces. This analysis also shows that complex sand sheet, dune and channel architectures have lithological significance but cannot be recorded on standard resolution gamma ray measurements. Several characteristics of strait-adjacent tidal dominated systems are outlined and compared to 'true' confined tidal strait deposits which tend to develop in narrower geographies. This shows that confined tidal strait deposits are different from strait-adjacent deltas as the latter have an asymmetric facies arrangement, and an overall basinward 
reduction in depositional energy. Strait-adjacent deltas are more similar to conventional tidedominated deltas with some exceptions: 1) Strait-adjacent deltas have a proportionally large delta front component containing thick intervals of coarse grained dune and channel bearing facies, 2) strait-adjacent deltas can have upward rotary palaeocurrent trends, which is associated with continual progradation of the delta system and a gradual increase of the alongshore tidal currents.

3) Strait-adjacent systems have a relative lack of sedimentary structures associated with waves and 4), muddy flat facies are largely absent and sand sheet bearing delta plain facies are more extensive.

\section{REFERENCES}

Abouessa, A. Duringer, P. Schuster, M. Pelletier, J. \& Rubino, J. L. 2014. Small-scale sedimentary structures and their implications in recognizing large-scale ancient tidal bedforms. Example from Dur At Talah outcrop, Late Eocene, Sirt Basin, Libya. Journal of African Earth Sciences, 100, 346-364, https://doi.org/10.1016/j.jafrearsci.2014.07.008

Abbassi, A. Cipollari, P. Zaghloul, M. N. and Cosentino, D. 2020. The Rif Chain (Northern Morocco) in the Late Tortonian-Early Messinian Tectonics of the Western Mediterranean Orogenic Belt: Evidence From the Tanger-Al Manzla Wedge-Top Basin. Tectonics, 39(9), https://doi.org/10.1029/2020TC006164

Achalhi, M. Münch, P. Cornée, J. J. Azdimousa, A. Melinte-Dobrinescu, M. Quillévéré, F. Drinia, H. Fauquette, G. J-D. Merzeraud, G. Ben Moussa, A. El Kharim, Y. Feddi, N. and Feddi, N. 2016. The late Miocene Mediterranean-Atlantic connections through the north Rifian Archipelago: new insights from the Boudinar and Arbaa Taourirt basins (northeastern Rif, Morocco). Palaeogeography, $\quad$ Palaeoclimatology, $\quad$ Palaeoecology, $\quad 459, \quad 131-152$, https://doi.org/10.1016/j.palaeo.2016.06.040

Adams, J. A. and Weaver, C. E. 1958. Thorium-to-uranium ratios as indicators of sedimentary processes: example of concept of geochemical facies. AAPG Bulletin, 42(2), 387-430, https://doi.org/10.1306/0BDA5A89-16BD-11D7-8645000102C1865D

Allen, P. A. and Homewood, P. 1984. Evolution and mechanics of a Miocene tidal sandwave. Sedimentology, 31(1), 63-81, https://doi.org/10.1111/j.1365-3091.1984.tb00723.x

Beelen, D. Wood, L. Zaghloul, M. N. Haissen, F. Arts, M. Ouahbi, I.. Redouane, M. and Cardona, S. 2020. Tide-dominated deltas responding to high-frequency sea-level changes, PreMessinian Rifian Corridor, Morocco. Journal of Sedimentary Research, 90(11), 1642-1666, https://doi.org/10.2110/jsr.2020.010

Beelen, D. Wood, L. J. Zaghloul, M. N. Arts, M. \& Sarg, F. 2021. Shallow or deep? A reinterpretation of the Rifian Corridor's unique sandy contourites. Preprint in EarthArXiv, 2107

Bernini, M. Boccaletti, M. Moratti, G. \& Papani, G. 2000. Structural development of the TazaGuercif Basin as a constraint for the Middle Atlas Shear Zone tectonic evolution. Marine and Petroleum Geology, 17(3), 391-408, https://doi.org/10.1016/S0264-8172(99)00042-2 
Blondeaux, P. and Vittori, G. 2011. The formation of tidal sand waves: Fully three-dimensional versus shallow water approaches. Continental Shelf Research, 31(9), 990-996, https://doi.org/10.1016/j.csr.2011.03.005

Bouma, A. 1964. Turbidites. In Developments in sedimentology, 3, 247-256, Elsevier. https://doi.org/10.1016/S0070-4571(08)70967-1

Buatois, L. A. Santiago, N. Herrera, M. Plink-Björklund, Piret, Steel, Ron, Espin, M. and Parra, K. 2012. Sedimentological and ichnological signatures of changes in wave, river and tidal influence along a Neogene tropical deltaic shoreline. Sedimentology, 59(5), 1568-1612, https://doi.org/10.1111/j.1365-3091.2011.01317.x

Capella, W. Hernández-Molina, F. J. Flecker, R. Hilgen, F. J. Hssain, M. Kouwenhoven, T. J. and Krijgsman, W. 2017. Sandy contourite drift in the late Miocene Rifian Archipelago (Morocco): Reconstruction of depositional environments in a foreland-basin seaway. Sedimentary Geology, 355, 31-57, https://doi.org/10.1016/j.sedgeo.2017.04.004

Chenakeb, M. 2004. Carte Géologique du Maroc, Feuille Beni Ammar, echelle 1: 50,000: Notes et Memoires Service Géologique du Maroc, 428

Costello, W. R. \& Southard, J. B. 1981. Flume experiments on lower-flow-regime bed forms in coarse sand. Journal of Sedimentary Research, 51(3), 849-864, https://doi.org/10.1306/212F7DC4-2B24-11D7-8648000102C1865D

Dalrymple, R. W. and Rhodes, R. N. 1995. Estuarine dunes and bars. In Developments in sedimentology 53, 359-422, Elsevier, https://doi.org/10.1016/S0070-4571(05)80033-0

Dalrymple, R. W. and Choi, K. 2007. Morphologic and facies trends through the fluvial-marine transition in tide-dominated depositional systems: a schematic framework for environmental and sequence-stratigraphic interpretation. Earth-Science Reviews, 81(3-4), 135-174, https://doi.org/10.1016/j.earscirev.2006.10.002

Davis Jr, R. A. and Dalrymple, R. W. (eds) 2011. Principles of tidal sedimentology. Springer Science and Business Media, https://doi.org/10.1007/978-94-007-0123-6

Desjardins, P. R. Buatois, L. A.and Mangano, M. G. 2012. Tidal flats and subtidal sand bodies. Developments in Sedimentology, 64, 529-561, https://doi.org/10.1016/B978-0-444-538130.00018-6

Devries Klein, G. 1971. A sedimentary model for determining palaeotidal range. Geological Society of America Bulletin, 82(9), 2585-2592, https://doi.org/10.1130/00167606(1971)82[2585:ASMFDP]2.0.CO;2

de Weger, W. Hernández-Molina, F. J. Flecker, R. Sierro, F. J. Chiarella, D. Krijgsman, W. and Manar, M. A. 2020. Late Miocene contourite channel system reveals intermittent overflow behavior. Geology, 48(12), 1194-1199, https://doi.org/10.1130/G47944.1 
Dunham, R. J. 1962. Classification of carbonate rocks according to depositional textures

Flemming, B. W. \& Kudrass, H. R. 2018. Large dunes on the outer shelf off the Zambezi Delta, Mozambique: evidence for the existence of a Mozambique Current. Geo-Marine Letters, 38(1), 95-106, https://doi.org/10.1007/s00367-017-0515-5

Gani, M. R. Bhattacharya, J. P. and Maceachern, J. A. 2009. Using ichnology to determine relative influence of waves, storms, tides, and rivers in deltaic deposits: examples from Cretaceous Western Interior Seaway, USA

Gingras, M. K. and MacEachern, J. A. 2012. Tidal ichnology of shallow-water clastic settings. In Principles of Tidal Sedimentology 57, 77, Springer, Dordrecht, https://doi.org/10.1007/978-94007-0123-6_4

Greb, S. F. and Archer, A. W. 2007. Soft-sediment deformation produced by tides in a meizoseismic area, Turnagain Arm, Alaska. Geology, 35(5), 435-438. https://doi.org/10.1130/G23209A.1

James, N. P. Seibel, M. J. Dalrymple, R. W. Besson, D. and Parize, O. 2014. Warm-temperate, marine, carbonate sedimentation in an Early Miocene, tide-influenced, incised valley; Provence, south-east France. Sedimentology, 61(2), 497-534, https://doi.org/10.1111/sed.12063

Iribarren, L. Vergés, J. \& Fernàndez, M. 2009. Sediment supply from the Betic-Rif orogen to basins through Neogene. Tectonophysics, 475(1), 68-84, https://doi.org/10.1016/j.tecto.2008.11.029

Ivanovic, R. F. Flecker, R., Gutjahr, M. \& Valdes, P. J. 2013. First Nd isotope record of Mediterranean-Atlantic water exchange through the Moroccan Rifian Corridor during the Messinian salinity crisis. Earth and Planetary Science Letters, 368, 163-174. https://doi.org/10.1016/j.eps1.2013.03.010

Knaust, D. and Bromley, R. G. (eds) 2012. Trace fossils as indicators of sedimentary environments, Newnes, https://doi.org/10.1016/B978-0-444-53813-0.00024-1

Krijgsman, W. Hilgen, F. J. Raffi, I. Sierro, F. J. and Wilson, D. S. 1999. Chronology, causes and progression of the Messinian salinity crisis. Nature, 400(6745), 652-655, https://doi.org/10.1038/23231

Legler, B. Johnson, H. D. Hampson, G. J. Massart, B. Y. Jackson, C. A. L. Jackson, M. D. \& Ravnas, R. 2013. Facies model of a fine-grained, tide-dominated delta: lower Dir Abu Lifa Member (Eocene), Western Desert, Egypt. Sedimentology, 60(5), 1313-1356, https://doi.org/10.1111/sed.12037

Longhitano, S. G. 2013. A facies-based depositional model for ancient and modern, tectonicallyconfined tidal straits. Terra Nova, 25(6), 446-452, https://doi.org/10.1111/ter.12055 
Longhitano, S. G. Mellere, D. Steel, R. J. and Ainsworth, R. B. 2012. Tidal depositional systems in the rock record: a review and new insights. Sedimentary Geology, 279, 2-22, https://doi.org/10.1016/j.sedgeo.2012.03.024

Longhitano, S. G. \& Steel, R. J. 2017. Deflection of the progradational axis and asymmetry in tidal seaway and strait deltas: insights from two outcrop case studies. Geological Society, London, Special Publications, 444(1), 141-172, https://doi.org/10.1144/SP444.8

Liu, L. Y. Skidmore, E. Hasi, E. Wagner, L. \& Tatarko, J. 2005. Dune sand transport as influenced by wind directions, speed and frequencies in the Ordos Plateau, China. Geomorphology, 67(3-4), 283-297, https://doi.org/10.1016/j.geomorph.2004.10.005

Maceachern, J. A. Bann, K. L.Bhattacharya, J. P. and Howell Jr, C. D. 2005, Ichnology of deltas: organism responses to the dynamic interplay of rivers, waves, storms, and tides

Martín, J. M. Puga-Bernabéu, A. Aguirre, J. \& Braga, J. C. 2014, Miocene Atlantic-Mediterranean seaways in the Betic Cordillera (Southern Spain). Revista de la Sociedad Geológica de España, 27(1), 175-186

Nienhuis, J. H. Ashton, A. D. Edmonds, D. A. Hoitink, A. J. F. Kettner, A. J. Rowland, J. C. and Törnqvist, T. E. 2020. Global-scale human impact on delta morphology has led to net land area gain. Nature, 577(7791), 514-518, https://doi.org/10.1038/s41586-019-1905-9

Olariu, C. Steel, R. J. Dalrymple, R. W. and Gingras, M. K. 2012. Tidal dunes versus tidal bars: The sedimentological and architectural characteristics of compound dunes in a tidal seaway, the lower Baronia Sandstone (Lower Eocene), Ager Basin, Spain. Sedimentary Geology, 279, 134155

Pemberton, S. G. and Frey, R. W. 1984. Ichnology of storm-influenced shallow marine sequence: Cardium Formation (Upper Cretaceous) at Seebe, Alberta. https://doi.org/10.1016/j.sedgeo.2012.07.018

Pemberton, S. G. and Wightman, D. M. 1992. Ichnological characteristics of brackish water deposits

Rhoads, D. C. 1975. The palaeoecological and environmental significance of trace fossils. In The study of trace fossils 147-160. Springer, Berlin, Heidelberg, https://doi.org/10.1007/978-3-64265923-2_9

Rich, J. L. Three critical environments of deposition, and criteria for recognition of rocks deposited in each of them. Geological Society of America Bulletin, 1951, 62.1: 1-20

Rossi, V. M. Longhitano, S. G. Mellere, D. Dalrymple, R. W. Steel, R. J. Chiarella, D. and Olariu, C. 2017. Interplay of tidal and fluvial processes in an early Pleistocene, delta-fed, strait margin 
(Calabria, Southern Italy). Marine and Petroleum Geology, 87, 14-30. https://doi.org/10.1016/j.marpetgeo.2017.02.021

Roldán, F. J. Galindo-Zaldívar, J. Ruano, P. Chalouan, A. Pedrera, A. Ahmamou, M. RuizConstána C. Sanz de Galdeanoc, Benmakhlouf, M. López-Garridoc, A.C. Anahnah. F. and González-Castillo, L. 2014. Basin evolution associated to curved thrusts: The Prerif Ridges in the Volubilis area (Rif Cordillera, Morocco). Journal of Geodynamics, 77, 56-69. https://doi.org/10.1016/j.jog.2013.11.001

Roveri, M. Flecker, R. Krijgsman, W.Lofi, J. Lugli, S. Manzi, V. Sierro, F. J. Bertini, A. Camerlenghi, A. de Lange, G-J. Govers, R. Hilgen, F. J. Hübscher, C. Meijer, P. Th.and Stoica, M. 2014. The Messinian Salinity Crisis: past and future of a great challenge for marine sciences. Marine Geology, 352, 25-58, https://doi.org/10.1016/j.margeo.2014.02.002

Rivers, J. M. Dalrymple, R. W. Yousif, R. Al-Shaikh, I. Butler, J. D. Warren, C. Skeat, L. S. and Bari, E. M. A. 2020. Mixed siliciclastic-carbonate-evaporite sedimentation in an arid eolian landscape: The Khor Al Adaid tide-dominated coastal embayment, Qatar. Sedimentary Geology, 408, 105730, https://doi.org/10.1016/j.sedgeo.2020.105730

Schlumberger. 2013. Schlumberger log interpretation charts. Houston, Texas, USA

Yalin, M. S. 1964. Geometrical properties of sand wave. Journal of the Hydraulics Division, 90(5), 105-119, https://doi.org/10.1061/JYCEAJ.0001097

Zizi, Mahmoud. Triassic-Jurassic extensional systems and their Neogene reactivation in northern Morocco (the Rides prérifaines and Guercif basin). 1996. PhD Thesis

\section{ACKNOWLEDGEMENTS}

We thank Professor Faouziya Haissen for her help and initiative in organizing our expedition. We also thank Mouttaqi Abdellah and Ismail Ouahbi from OHNYM for their extraordinary courtesy and logistic support. Finally, we express our thanks to Meryem Redouane for her assistance in the field.

\section{CONFLICTS OF INTEREST}

There are no financial or other conflicts of interest.

\section{AUTHOR CONTRIBUTIONS}

Daan Beelen developed the original idea, performed the research, and wrote the manuscript. Lesli Wood provided academic and logistic support and contributed to the conception of the manuscript. Mohamed Najib Zaghloul aided in the fieldwork and provided academic support and contributed to the conception of the manuscript. Michiel Arts aided in the fieldwork and provided academic support. Sebastian Cardona aided in the fieldwork and provided academic support. 


\section{FUNDING INFORMATION}

Funding was provided through the SAnD Consortium. Additional funding was provided by the Bartshe endowment.

\section{DATA AVAILABILITY}

All data generated or analysed during this study are included in this published article (and its supplementary information files). 